\title{
Limestone-Mediated Suppression of Fusarium Wilt in Spinach Seed Crops
}

\author{
Emily W. Gatch and Lindsey J. du Toit, Washington State University, Mount Vernon Northwestern Washington Research \& Extension
} Center, Mount Vernon 98273-4768

\begin{abstract}
Fusarium wilt of spinach is caused by the soilborne fungus Fusarium oxysporum f. sp. spinaciae and occurs in most regions of spinach production. The disease is favored by acid soils and warm temperatures, and the fungus can survive extended periods as chlamydospores or by asymptomatic colonization of the roots of nonhost plant species. The 10- to 15 -year rotation required to minimize losses to Fusarium wilt is the primary constraint on spinach seed production in the maritime Pacific Northwest, the only region of the United States suitable for this cool-season, daylength-sensitive crop. Raising soil $\mathrm{pH}$ with agricultural limestone $\left(97 \% \mathrm{CaCO}_{3}\right)$ results in a transitory, partially suppressive effect on spinach Fusarium wilt. A field trial was completed from 2009 to 2012 to assess the potential for annual applications of agricultural limestone at $0,2.24$, and 4.48 tons/ha for 3 years prior to a spinach seed crop to improve Fusarium wilt suppression compared with the level of suppression attained from a single limestone amendment at 4.48 tons/ha. Three proprietary female spinach lines were planted

that ranged from highly susceptible to partially resistant to Fusarium wilt. Three successive annual applications of limestone at 4.48 tons/ha reduced midseason wilt incidence by an average of $20 \%$, increased spinach biomass by $33 \%$, and increased marketable spinach seed yield by $45 \%$ compared with plots amended once with the same rate of limestone in the spring of planting. The suppressive effect increased with increasing rate of limestone amendment, with the greatest difference observed when limestone was applied at between 0 and 2.24 tons/ha annually for 3 years. The effects on seed yield were greatest for the partially resistant female line, followed by the moderately susceptible and highly susceptible female lines. Overall, the results demonstrate that annual applications of agricultural limestone on acid soils of the maritime Pacific Northwest of the United States can enhance suppression of spinach Fusarium wilt, potentially reducing the required rotation interval by as much as $50 \%$, thereby doubling the capacity for spinach seed production in the United States.
\end{abstract}

Demand for spinach (Spinacia oleracea) has increased sharply since the advent in the mid-1990s of fresh-market, prepackaged, baby and "teenage" leaf spinach, now the dominant spinach commodity produced in California and Arizona (Koike et al. 2011). Baby leaf spinach crops are short-season (20 to 40 days from planting to harvest), high-density plantings with populations of $\leq 9 \mathrm{million} \mathrm{seed} / \mathrm{ha}$, compared with $300,000 \mathrm{seed} / \mathrm{ha}$ for processing spinach crops. Although spinach can be grown for fresh or processing markets in many different regions, spinach seed production requires a long summer daylength to initiate bolting (conversion from vegetative to reproductive growth), mild summer temperatures, and low relative humidity as well as limited rainfall during seed maturation to ensure optimal seed quality (Metzger and Zeevaart 1985). The maritime Pacific Northwest (PNW) is the only region of the United States, and one of the few regions in the world, that meets these exacting requirements for spinach seed production (Foss and Jones 2005) and is the source of up to $50 \%$ of the U.S. spinach seed supply and up to $20 \%$ of the global spinach seed supply.

The primary limit to spinach seed production in the PNW is Fusarium wilt, caused by the soilborne fungus Fusarium oxysporum f. sp. spinaciae (Foss and Jones 2005). Rotations of at least 10 years are necessary to avoid economic losses to Fusarium wilt in PNW spinach seed crops (du Toit 2004; Foss and Jones 2005). When the disease was first reported in this region in the 1950s, losses were avoided

Corresponding author: L. J. du Toit; E-mail: dutoit@wsu.edu

PPNS 0713, Department of Plant Pathology, College of Agricultural, Human, and Natural Resource Sciences, Agricultural Research Center, Hatch Project Numbers WPN00595 and WPN05595, Washington State University, Pullman, 99164-6430.

*The $\boldsymbol{e}$-Xtra logo stands for "electronic extra" and indicates that four supplementary tables are published online.

Accepted for publication 9 August 2016.

@ 2017 The American Phytopathological Society by limiting spinach seed production to fields that had never been planted to spinach; however, such ground is now virtually nonexistent. Partially resistant spinach parent lines exist but many of the parent lines used widely for seed crops are highly susceptible to the disease (du Toit 2004). Furthermore, spinach seed is grown on a contractual basis (Foss and Jones 2005), and growers as well as some seed company representatives may not know the level of Fusarium wilt resistance of the parent lines provided. In contrast, Fusarium wilt typically has been of minor importance for freshmarket and processing spinach crops (Correll et al. 1994); therefore, breeding for resistance to Fusarium wilt has not been a high priority (J. Schafer, spinach breeder, Schafer Agricultural Services, personal communication). The long rotation required between seed crops is a hardship for spinach seed growers but also affects end users of spinach seed in terms of seed availability. With the additional requirement to maintain isolation distances of 1.0 to $6.4 \mathrm{~km}$ between adjacent spinach seed crops to prevent undesirable cross-pollination, the carrying capacity of farmland in the maritime PNW for spinach seed crops has peaked. In contrast, spinach seed acreage in northern Europe, where Fusarium wilt is not a major concern, has continued to expand, with Denmark now the top producer of spinach seed for western hemisphere markets (van Veldhuizen 2011). On the calcareous, alkaline soils of Denmark, spinach seed crops typically are grown on a 5-year rotation with minimal losses to Fusarium wilt.

Variation in conduciveness of soils to Fusarium wilts has been the subject of scrutiny (Scher and Baker 1980; Toussoun 1975). In various regions of the world, the existence of soils that are in some way inhospitable to Fusarium wilts has prompted exploration of biotic and abiotic mechanisms of disease suppression. Early in the 20th century, researchers established a connection between soil chemistry and Fusarium wilt severity in certain crops. Edgerton (1918) found that soil application of limestone at 22.4 metric tons ( $t$ )/ha significantly reduced the incidence of Fusarium wilt of tomato (Solanum lycopersicon) in seed beds and in the field. Sherwood (1923) explored this response in greenhouse experiments with a sandy loam soil and a silt loam soil, each sterilized and amended with limestone, inoculated with $F$. oxysporum f. sp. lycopersici, and planted with a susceptible tomato cultivar. In both soils, a decrease in wilt was associated with an increase in $\mathrm{pH}$. Sherwood also found that 
the greatest pathogen biomass production occurred between $\mathrm{pH}$ 2.8 and 5.0 when he inoculated culture media with the pathogen and adjusted the medium to a range of $\mathrm{pH}$ levels using $\mathrm{NaOH}$ or $\mathrm{HCl}$.

Similar research was completed in Florida when Woltz and Jones (1981) devised a nutritional approach for management of several Fusarium wilts based on the suppressive effect of soil $\mathrm{pH}$ elevation. Experiments with watermelon (Citrullus lanatus) (Everett and Blazquez 1967; Jones and Woltz 1975), cucumber (Cucumis sativus) (Jones and Woltz 1975), tomato (Jones and Overman 1971; Jones and Woltz 1970, 1972; Woltz and Jones 1973), and chrysanthemum (Chrysanthemum spp.) (Woltz and Engelhard 1973) demonstrated that alkalizing soil amendments, including calcium carbonate $\left(\mathrm{CaCO}_{3}\right)$, calcium oxide ( $\mathrm{CaO}$, also called burned lime), and calcium hydroxide $\left(\mathrm{Ca}(\mathrm{OH})_{2}\right.$, also called hydrated lime), reduced losses to Fusarium wilt. To address the possibility that the suppressive effects could be due to increased soil calcium (Ca) levels resulting from the amendments, steps were taken to equalize $\mathrm{Ca}$ levels regardless of limestone treatment (Jones and Overman 1971) or to compare alkalizing $\mathrm{Ca}$ compounds such as $\mathrm{CaCO}_{3}$ with nonalkalizing amendments such as calcium sulfate $\left(\mathrm{CaSO}_{4}\right)$ (Everett and Blazquez 1967; Jones and Woltz 1970). The results confirmed that increased soil $\mathrm{pH}$, not Ca supply, was the factor most closely associated with Fusarium wilt suppression in these crops.

In addition to soil $\mathrm{pH}$, the form of nitrogen $(\mathrm{N})$ fertilizer is a factor influencing Fusarium wilt, specifically the presence of ammonium $\left(\mathrm{NH}_{4}{ }^{+}\right)$or nitrate $\left(\mathrm{NO}_{3}{ }^{-}\right)$as the nitrogenous ion. Both high $\mathrm{pH}$ and $\mathrm{NO}_{3}{ }^{-}-\mathrm{N}$ reduced virulence of $F$. oxysporum $\mathrm{f}$. sp. vasinfectum on cotton (Gossypium spp.) (Albert 1946). For Fusarium wilts of tomato (Woltz and Jones 1973), chrysanthemum (Woltz and Engelhard 1973), cucumber and watermelon (Jones and Woltz 1975), and celery (Apium graveolens) (Schneider 1985), use of $\mathrm{NH}_{4}{ }^{+}$- versus $\mathrm{NO}_{3}{ }^{-} \mathrm{N}$ fertilizers negated the suppressive effect of increased soil $\mathrm{pH}$. Root uptake of the $\mathrm{NO}_{3}{ }^{-}$ion causes an increase in soil $\mathrm{pH}$, whereas uptake of the $\mathrm{NH}_{4}{ }^{+}$ion acidifies the surrounding soil (Havlin et al. 1999); thus, it is possible that the mechanisms underlying the suppressive effect of limestone application and $\mathrm{NO}_{3}{ }^{-}-\mathrm{N}$ fertilization are similar. When F. oxysporum f. sp. lycopersici was cultured in a liquid medium with $\mathrm{NH}_{4}{ }^{+}$or $\mathrm{NO}_{3}{ }^{-}$as the $\mathrm{N}$ source, spores harvested from $\mathrm{NH}_{4}{ }^{+}$treatments were more virulent on inoculated tomato seedlings compared with spores cultured in $\mathrm{NO}_{3}{ }^{-}$media, suggesting that there could also be a direct effect of $\mathrm{N}$ source on fungal physiology (Woltz and Jones 1973).

Generalities about relationships between soil $\mathrm{pH}$ and all Fusarium wilts are ill advised, and caution is required when applying concepts of disease suppression to different regions and cropping systems. The effects of soil $\mathrm{pH}$ and $\mathrm{N}$ source on watermelon Fusarium wilt observed by Jones and Woltz (1975) could not be duplicated by Hopkins and Elmstrom (1976). Similarly conflicting results have been observed for the influence of soil $\mathrm{pH}$ on Fusarium wilts of banana (Musa acuminata) (Peng et al. 1999; Stover 1956), strawberry (Fragaria ananassa) (Fang et al. 2012; Islas 2012), and flax (Linum spp.) (Höper et al. 1995). Furthermore, the alkaline soils of Arizona are conducive to Fusarium wilt of lettuce (Lactuca sativa) (Matheron and Koike 2003). Part of the challenge in using these studies to develop disease management strategies is that the mechanisms underlying suppression through manipulation of abiotic soil properties such as $\mathrm{pH}$ and $\mathrm{N}$ source are not well understood. The association between Fusarium wilt suppression and environmental factors is typically related, in part, to the effects of these factors on the soil microbiota, members of which may compete directly with or release toxins against the pathogen, or incite plant host defense responses (Baker and Cook 1974).

From 2006 to 2008, field trials were completed in the Skagit Valley of northwestern Washington to determine whether the limestone-mediated suppression of Fusarium wilt observed in other crops could be deployed to manage Fusarium wilt in spinach seed crops (du Toit et al. 2007, 2008, 2011). Although results varied with the level of Fusarium wilt resistance of the spinach parent lines and trial location, agricultural limestone applied approximately 2 weeks prior to planting proved effective. An application rate of $4.48 \mathrm{t} / \mathrm{ha}$ was optimal for suppressing the disease and avoiding nutritional imbalances that occurred at greater application rates. However, the elevation of soil $\mathrm{pH}$ also increased the incidence of Verticillium wilt caused by Verticillium dahliae (du Toit et al. 2007, 2011). This disease is a concern in spinach seed crops because the fungus is readily seedborne and seed transmitted (du Toit et al. 2005; Feng et al. 2014), and some strains that infect spinach can infect crops grown in rotation with spinach in states such as California and Arizona, two major markets for PNW spinach seed (Atallah et al. 2011; Bhat and Subbarao 1999; Iglesias-Garcia et al. 2013). In general, Verticillium wilts are enhanced by high soil $\mathrm{pH}$ and $\mathrm{NO}_{3}{ }^{-}-\mathrm{N}$ fertilizers (Lambert et al. 2005; Smiley 1975), in contrast to many Fusarium wilts.

The use of limestone amendments in spinach seed crops has intensified in response to these studies in northwestern Washington (du Toit and Gatch 2009). However, the benefit of such applications is presumed to be short lived, given that soils in this region are well buffered and revert readily to an acidic, Fusarium-wilt-conducive state well before the next spinach seed crop is planted. Most growers are reluctant to apply limestone regularly because some crops grown in rotation with spinach seed are either not valuable enough to recover the cost of regular limestone amendment (e.g., wheat [Triticum aestivum]) or do not require limestone for optimum yields. Also, the long rotation requirement and regional urban development pressure limit availability of land suitable for spinach seed production, necessitating convoluted land rental arrangements and annual negotiations between growers and seed companies (K. Johnson, President, Puget Sound Seed Growers' Association, personal communication). This complicates long-term strategies for managing spinach Fusarium wilt. However, the persistent nature and destructive potential of Fusarium wilt in these acid soils may require annual applications of limestone for several years preceding a spinach seed crop, rather than one application in the spring a spinach seed crop is planted. If this approach proves effective, growers could employ shorter rotations and produce a greater percentage of their spinach seed crops on their own land, thereby increasing return on investment for repeated limestone applications. In 2009, a 4-year field trial was initiated in Skagit County, WA to evaluate the effects of the following on Fusarium wilt and Verticillium wilt in spinach seed production: (i) annual limestone applications for 3 years prior to a spinach seed crop compared with a single application the spring of planting, and (ii) $\mathrm{NO}_{3}{ }^{-}-\mathrm{N}$ versus $\mathrm{NH}_{4}{ }^{+} \mathrm{N}$ fertilizers. This was part of a larger project on management of Fusarium wilt in spinach seed crops in the PNW of the United States (Gatch 2013; Gatch and du Toit 2015; Gatch et al. 2011; Okubara et al. 2013).

\section{Materials and Methods}

Field site. A 0.8-ha section of a grower-cooperator field in Skagit County, WA was selected for the 4-year trial. The field had been planted to a spinach seed crop by the grower in 2005, followed by pumpkin (Cucurbita pepo), a Brassica seed crop, and winter wheat in 2006 to 2008. The soil was classified as a Mount Vernon very fine sandy loam (USDA Soil Survey Staff 2016) and had a pH of 5.9 in March 2009 (Soiltest Farm Consultants, Inc., Moses Lake, WA).

Experimental and treatment designs. In 2009, three rates of agricultural limestone application, three proprietary female spinach inbred lines, and two $\mathrm{N}$ fertilizers were evaluated using a three-bythree-by-two factorial, split-split plot, randomized complete block design, with five replications of each treatment combination. $\mathrm{N}$ fertilizer treatments were applied to main plots, spinach lines were planted in split plots, and limestone amendment rates were applied to splitsplit plots. The limestone treatments consisted of agricultural limestone at $0,2.24$, or 4.48 t/ha (Imperial Ground limestone, Oregon Lime Score $=97$, calcium carbonate equivalent $=97 \%, 97 \% \mathrm{CaCO}_{3}$, and $38.8 \% \mathrm{Ca}$ ), with the rates chosen based on results of previous trials (du Toit et al. 2007, 2008, 2011). The three proprietary spinach inbred lines had previously been characterized as highly susceptible, moderately susceptible, and moderately resistant to Fusarium wilt (referred to henceforth as susceptible, moderate, and resistant inbreds, respectively). The in-furrow, at-planting fertilizer treatments 
included monoammonium phosphate (11-52-0), which is typically used by spinach seed growers in western Washington (Jeff Schwab, Wilbur-Ellis Co., personal communication) and is an acidifying fertilizer (acidity score $=58)$; and calcium nitrate $(15.5-0-0)$, an alkalizing fertilizer supplied at equivalent units of $\mathrm{N}$. The addition of phosphorus at $67 \mathrm{~kg} / \mathrm{h}$ with the $\mathrm{NH}_{4}{ }^{+}-\mathrm{N}$ fertilizer and $\mathrm{Ca}$ at $22 \mathrm{~kg} / \mathrm{ha}$ with the $\mathrm{NO}_{3}{ }^{-} \mathrm{N}$ fertilizer were potential confounding factors, although soil tests did not indicate a deficiency of either nutrient.

In 2010 and 2011, the grower planted potato (S. tuberosum) and winter wheat, respectively, using typical production practices for northwestern Washington. The limestone treatments applied in the 2009 spinach trial were applied again to the same plots in April 2010 prior to planting the potato crop, and again in September 2011 after harvest of the winter wheat crop (Fig. 1). In 2012, the spinach seed crop trial was repeated in the same plots established in 2009, with several modifications. A major precipitation event $(2.5 \mathrm{~cm}$ in 1 day) within 2 weeks of planting the 2009 spinach trial caused leaching of the $\mathrm{NO}_{3}{ }^{-}$, with subsequent $\mathrm{N}$ deficiency observed on spinach plants in all main plots treated with $\mathrm{CaNO}_{3}$ fertilizer. This treatment was deemed inappropriate for the very wet spring conditions typical of the maritime PNW; therefore, the treatment was not evaluated again in 2012. The plots that received no limestone in 2009 to 2011 were each divided in two in spring 2012, with half of each plot receiving no limestone and the other half receiving limestone at $4.48 \mathrm{t} / \mathrm{ha}$ within 1 month of planting. The latter simulated the common practice of limestone amendment for spinach seed crops in this region (i.e., application of limestone at $4.48 \mathrm{t} / \mathrm{ha}$ in the spring that a spinach seed crop is planted). Thus, the design of the 2012 field trial became a randomized split block, with three spinach inbred lines in main plots and four limestone treatments in split plots (Fig. 1).

Field planting and maintenance. 2009. Following a winter wheat crop in 2008-09, the field site was chiseled and plowed on 8 April 2009. On 22 April, cycloate (RoNeet; Helm Agro US, Memphis, TN) applied at 3 liters/ha, and diazinon (Diazinon; MANA Inc., Raleigh, NC) applied at 4.7 liters/ha were broadcast and incorporated with a mulcher-packer for weed and insect control, respectively (Foss and Jones 2005). Limestone was applied on 10 April at 0, 2.24 , and 4.48 t/ha with a 1.8-m-wide Gandy drop spreader (Gandy, Owatonna, MN), and rototilled 15 to $20 \mathrm{~cm}$ deep. Spinach seed were planted on 22 April (1.3 cm deep) using a Monosem planter (Monosem, Edwardsville, KS), with $56-\mathrm{cm}$ spacing between rows and $6.4-\mathrm{cm}$ spacing within rows. Six 9-m-long rows of the appropriate female line were planted in each split plot, with one row of a proprietary male line on each side of the six female rows. The male line was the same as that of the nearest commercial spinach seed crop in order to avoid violating the minimum required pollen isolation requirements for spinach seed crops established by the Western Washington Small Seed Advisory Committee (1998). Fertilizer treatments were applied in furrow at planting to main plots: $11-52-0$ monoammonium phosphate (308 kg/ha) or 15-5-0 calcium nitrate (114 kg/ha). Plots were hand weeded regularly, and a fertilizer side dressing (270-0) was applied at $200 \mathrm{~kg} / \mathrm{ha}$ on 5 June with a single-shank applicator.

2010-11. On 16 April 2010, limestone treatments were applied and incorporated into the same plots as described above for the 2009 trial. The grower then planted the field site and surrounding area to a fresh-market potato crop ('Cascade') on 19 April. The potato crop was harvested on 9 September, and a winter wheat crop was planted in late September 2010. In mid-August 2011, the winter wheat crop was harvested by the grower, and the same limestone treatments were applied and incorporated into the established plots on 8 September 2011, as described above.

2012. The field site was disked, chiseled, plowed, and mulched on 29 March and 6, 9, and 10 April 2012, respectively, to incorporate wheat stubble and volunteer plants. Limestone was applied at the relevant rates and incorporated on 11 and 12 April. Ro-Neet and Diazinon were broadcast and mulched on 23 April at the rates used in 2009. Two weeks of rain delayed planting until 8 May. Monoammonium phosphate amended with boron (10-50-0-0.55B) was applied in-furrow at planting $(373 \mathrm{~kg} / \mathrm{ha})$ to all plots. On 6 June, rows were cultivated for weed control, and plants were side dressed with 27-0-0 ( $224 \mathrm{~kg} / \mathrm{ha})$ on 13 June. Plots were hand weeded regularly. On 21 June, a foliar application of chelated manganese (Mn; 5\%) and zinc (Zn; 7\%) was applied to plants in all plots (each product at 2.33 liters/ha, Foli-Gro Zn and Mn; Wilbur Ellis Co., Walnut Creek, CA) to address the potential for micronutrient deficiencies in spinach plants growing in plots treated with limestone for multiple years. On 2 August, pyraclostrobin and boscalid (Pristine WG at $0.78 \mathrm{~kg} / \mathrm{ha}$; BASF Corp., Research Triangle Park, NC) were applied to manage Stemphylium and Cladosporium leaf spots of spinach (du Toit et al. 2004).

The following designations are used to reference multiyear limestone treatments: for the 2009 trial, limestone at $0,2.24$, and $4.48 \mathrm{t} / \mathrm{ha}$; for the 2010-12 trial, limestone applied each year for 3 years at 0 , 2.24 , and $4.48 \mathrm{t} / \mathrm{ha} /$ year; and limestone at $0 \mathrm{t} / \mathrm{ha}$ each year for 3 years plus $4.48 \mathrm{t} / \mathrm{ha}$ in $2012=0 / 4.48 \mathrm{t} / \mathrm{ha}$.

Soil chemical and microbial analyses. In 2009, soil samples (12 cores/plot, sampled $15 \mathrm{~cm}$ deep, then combined and mixed manually for each plot) were collected at 3-week intervals throughout the season to track changes in soil $\mathrm{pH}$ related to limestone treatments. On 5 May, 18 June, and 8 and 28 July, soil samples were collected from all split-split plots (limestone treatments). On 27 May, soil was sampled only from split plots (fertilizer-limestone treatment combinations) for evaluation of the effect of $\mathrm{N}$ fertilizer and limestone treatments on soil $\mathrm{pH}$. At the final, posttrial sampling on 18 August, soil was sampled from split-split plots for all treatment combinations. In 2010, the year a potato crop was grown, soil samples were collected

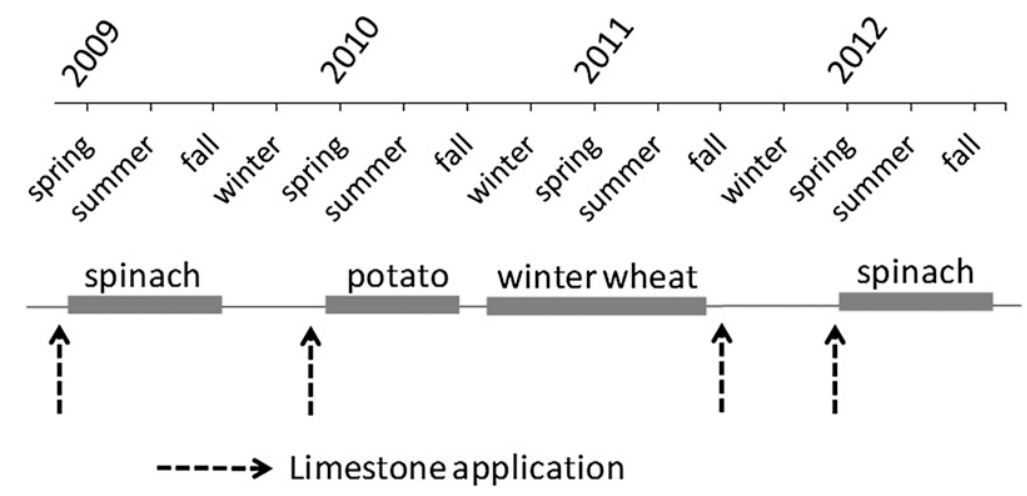

Fig. 1. Timeline of agricultural limestone applications in a field trial evaluating three annual applications versus one application of limestone to soil for suppression of Fusarium wilt in spinach seed crops in Skagit County, WA. The trial was located in a grower-cooperator's field that had previously been planted to a spinach seed crop in 2005 . Following the 2009 spinach seed crop trial, the grower planted a typical rotation of potato (2010) and winter wheat (2011). In 2012, the spinach seed crop trial was repeated in the same plots with the same limestone application rates and spinach inbred lines as the 2009 trial, to assess wilt severity. Limestone application rates of $0,2.24$, and 4.48 t/ha were applied to the same plots each season in 2009 to 2011. In 2012, a fourth limestone treatment was added in which control plots that had received no limestone from 2009 to 2011 were divided in half, with one half receiving no limestone and the other half amended with limestone at 4.48 tha (the 0/4.48 treatment) prior to planting the spinach trial. 
from split-split plots on 7 May (3 weeks after limestone application), 14 July (midseason), and 5 September (just prior to potato harvest). In 2011, when wheat was grown, soil samples were collected from split-split plots on 2 September (just prior to limestone application) and on 29 September ( 3 weeks after limestone application) to compare the soil $\mathrm{pH}$ before and after limestone application. In 2012, samples were collected from split plots (limestone treatments) on 10 April (prior to limestone application), 9 May (3 weeks after planting), and 9 to 10 July (midseason); and from parent line-limestone split plots on 24 August (after spinach seed harvest). Soil samples were collected using a $2.5-\mathrm{cm}$-diameter soil probe from between rows of spinach plants, with the exception of the final sampling in each of 2009 and 2012, when soil cores were collected between plants within spinach rows to assess the potential influence of spinach parent line on nutrient and microbial variables measured. Except for soil samples collected prior to limestone applications in 2011 and 2012, and main plot (parent line) samples collected in 2012, soils were shipped overnight to Soiltest Farm Consultants, Inc. for analysis of $\mathrm{NO}_{3}{ }^{-}-\mathrm{N}, \mathrm{NH}_{4}{ }^{-} \mathrm{N}$, phosphorus $(\mathrm{P})$, potassium $(\mathrm{K}), \mathrm{Ca}$, magnesium $(\mathrm{Mg})$, sodium $(\mathrm{Na}), \mathrm{pH}$, electrical conductivity, organic matter $(\mathrm{OM})$, sulfur (S), boron (B), Zn, Mn, copper, iron (Fe), cation exchange capacity (CEC), and buffer $\mathrm{pH}$.

Subsamples of soil collected on the first and last sampling dates in 2009 , the three sampling dates in 2010, the second sampling date in 2011, and the three sampling dates in 2012 were air dried, crushed with a marble rolling pin, and passed through a 1-mm aperture sieve. The dried subsamples were then assayed to quantify CFU of Fusarium oxysporum per gram of air-dried soil. A 10-g subsample of each was added to $100 \mathrm{ml}$ of sterilized, $0.1 \%$ water agar (WA) in a 240-ml glass French square, agitated on a rotary shaker at $250 \mathrm{rpm}$ for $10 \mathrm{~min}$, and diluted serially to a $10^{-2}$ concentration. An aliquot $(0.5 \mathrm{ml})$ of each of the $10^{-2}$ and $10^{-1}$ dilutions was placed onto each of three replicate, 95-mm-diameter plastic petri plates containing modified Komada's agar medium (Komada 1975; Scott et al. 2010), and the aliquot was distributed over the plate using a sterilized glass rod. The plates were incubated on a laboratory bench at room temperature $\left(25 \pm 2{ }^{\circ} \mathrm{C}\right)$ in ambient light in a room with windows. Fungal colonies with fluffy, white to pale salmon-pink colony morphology typical of $F$. oxysporum on this semiselective medium were counted 7 and 14 days after plating. This soil dilution plating assay does not differentiate colonies of $F$. oxysporum $\mathrm{f}$. sp. spinaciae from those of other formae speciales but provides an overall assessment of the influence of the various treatments on $F$. oxysporum populations. Although a real-time polymerase chain reaction (PCR) assay for the spinach Fusarium wilt pathogen has been developed (Okubara et al. 2013), extensive testing of that assay revealed a high degree of cross-reaction with nonpathogenic strains of $F$. oxysporum commonly associated with spinach plants or soil in which spinach seed crops are grown in western Washington. Therefore, the real-time PCR assay was not used in this study.

$V$. dahliae populations were quantified for the first and last soil sampling dates of both 2009 and 2012 by distributing a 1-g subsample of dried soil on the surface of each of 10 plates $(95 \mathrm{~mm}$ in diameter) of NP-10 agar medium, which is semiselective for Verticillium spp. (Goud and Termorshuizen 2003; Sorensen et al. 1991), using a separate, sterilized, 29.6-ml glass salt shaker (Tablecrafts Products Co., Gurnee, IL) for each subsample. The plates were incubated in the dark at $26^{\circ} \mathrm{C}$ for 28 days, and $V$. dahliae-type colonies were enumerated using a dissecting microscope. The total number of colonies on all 10 plates was summed to calculate $V$. dahliae CFU/g of soil.

Fusarium wilt and plant growth assessment. Spinach plant stand and incidence of damped-off or wilted spinach plants were counted in a 3-m section of each of the two middle rows/plot on 15 May, 4 and 24 June, and 14 July 2009 and on 29 May, 19 and 20 June, 9 and 10 July, $31 \mathrm{July}$, and 1 August 2012. For the latter two dates in 2012 , wilt severity of each plant was also assessed using a 0 -to-5 ordinal rating scale, with 0 representing a healthy, asymptomatic plant, 1 to 4 representing an increasing percentage of the plant wilting in $20 \%$ increments, and 5 representing a plant that had died due to wilt. The male inbred was included in these wilt assessments until the third rating in 2009 and the fourth rating in 2012, when senescence of the male line precluded further wilt ratings.

Isolations for plant pathogens were completed on 8 June 2009 and 29 May 2012 from wilted seedlings sampled across the trial for all four parent lines, in order to assess the causes of the very low incidence (approximately 1\%) of early season damping-off and wilt. Leaves were removed after washing the seedlings under running tapwater, and the remaining tissue was cut into pieces approximately $1 \mathrm{~cm}$ long with a sterilized blade; surface-sterilized for durations of 60,90 , and $120 \mathrm{~s}$ in $0.6 \% \mathrm{NaOCl}$ to increase the chance of recovering the causal agent and minimizing growth of saprophytic soilborne fungi colonizing dying plant roots; triple-rinsed in sterilized, distilled water; and dried; and the pieces plated onto potato dextrose agar (Difco Laboratories, Detroit) amended with chloramphenicol at $100 \mathrm{mg} / \mathrm{liter}$ (cPDA) and on WA amended with chloramphenicol. Fungi growing from these pieces were transferred to new plates of cPDA and examined microscopically to identify potential fungal or oomycete seedling pathogens.

On 29 June and 22 July 2009, and 11 July 2012, all plants in $1 \mathrm{~m}$ of row per parent line, regardless of Fusarium wilt symptoms, were dug carefully so that the root system remained attached. Soil was shaken from the plants, and the plants were placed in a brown paper sack, dried at approximately $35^{\circ} \mathrm{C}$ for 10 to 12 days, and weighed. A subsample of the dried plants was sent to Soiltest Farm Consultants, Inc. for plant nutrient analyses. Prior to drying the plants collected on 22 July 2009 and 11 July 2012, the root and crown of each plant were cut longitudinally and assessed for incidence of dark-brown to black vascular discoloration typical of spinach Fusarium wilt (du Toit et al. 2005, 2007; Hungerford 1923).

To evaluate potential effects of limestone treatments on yield and incidence of tuber diseases of the potato crop planted in 2010, potato tubers were harvested from $3 \mathrm{~m}$ of row per split-split plot (limestone treatments) on 8 September. Potato yield was determined based on weight of the total bulk yield from each $3 \mathrm{~m}$ of row, and the weight of tubers in each of the following commercial weight classes: $<57,57$ to 142,143 to 255 , and $>255 \mathrm{~g}$, and culls. The incidence of tuber diseases was also assessed for each split-split plot. This was done to address concerns expressed by regional potato growers that limestone amendments might exacerbate some potato tuber diseases; in particular, common scab caused by Streptomyces scabies.

Seed yield and quality. Seed were harvested by hand from plants in $3 \mathrm{~m}$ of the center four rows per split-split plot on 8 August 2009 and from 13 to 23 August 2012, based on maturity of the spinach parent lines. In 2009, whole plants were cut at the soil line and placed in an air drier at $26 \pm 3^{\circ} \mathrm{C}$ to avoid rainy conditions, prior to hand stripping the seed from the plants on 8 to 20 August. In 2012, plants were windrowed onto sections of Reemay fabric (Reemay, Inc., London) on the ground and dried for several days prior to hand stripping the seed. Seed were then cleaned and screened to marketable size (screen sizes 7 to 13) by first hand sieving to break up seed clusters and separate larger chaff, then passing the seed through a Clipper air screen seed cleaner (M-2B; Ferrell-Ross, Oklahoma City, OK), an inclined belt separator, and a table-top Clipper.

A subsample of 100 seeds/split-plot was tested for germination using a blotter assay modified from the protocol of the Association of Official Seed Analysts (AOSA 2008). Each of two sets of 50 seeds were placed between two pieces of Steel blue blotter paper (25.4 $\mathrm{cm}$ by $38.1 \mathrm{~cm}$, number 38 regular weight; Anchor Paper Co., St. Paul, MN) moistened with deionized water. The blotters were then rolled between wax paper $(61.0 \mathrm{~cm}$ by $91.4 \mathrm{~cm}$; Anchor Paper Co.), the rolls were placed upright in a plastic bag, and the seed were cold-stratified at $40^{\circ} \mathrm{C}$ for $72 \mathrm{~h}$ to break dormancy and incubated in a seed germinator (Stultz Scientific Engineering Corp., Springfield, IL) at $15^{\circ} \mathrm{C}$ in the dark. The number of germinated seed per plot was assessed after 7, 14, and 21 days. At 21 days, the percentages of abnormal seedlings, non-germinated hard seed, and rotten seed were also determined (AOSA 2008).

A freeze-blotter seed health assay for necrotrophic fungi, modified slightly from that described by du Toit et al. (2005), was carried out using an additional $100 \mathrm{seed} / \mathrm{split}$-plot. Seed were surface-sterilized 
in $1.2 \% \mathrm{NaOCl}$ for $60 \mathrm{~s}$ and triple-rinsed in sterilized, deionized water to reduce infestation levels of common saprophytic fungi such as Alternaria spp. that can interfere with detection of fungal spinach pathogens. After drying the seed overnight, the seed were placed on damp, sterilized blotters (Anchor Paper Co.) in sterilized, acrylic boxes $(10 \mathrm{~cm}$ by $10 \mathrm{~cm}, 32$ to 34 seeds/box; Hoffman Manufacturing, Inc., Jefferson, OR), incubated in the dark for $25 \mathrm{~h}$ to imbibe, frozen at $-20^{\circ} \mathrm{C}$ for $25 \mathrm{~h}$, and then incubated for 12 days at $24^{\circ} \mathrm{C}$ using a cycle of $12 \mathrm{~h}$ /day and $12 \mathrm{~h}$ /night with near-UV and cool white fluorescent light by day. Seed were examined 5, 9, and 14 days after plating using a dissecting microscope $(\times 8$ to $\times 100$ magnification). In 2012, a modified protocol (du Toit 2011) was used in which the seed were placed on NP-10 agar medium (approximately $0.5 \mathrm{~cm}$ deep) in the same acrylic boxes, with no $-20^{\circ} \mathrm{C}$ freezing step needed prior to incubation. The NP-10 and freeze-blotter methods are comparable for detection of fungi such as $V$. dahliae and Fusarium spp. on spinach seed (du Toit 2011).

Statistical analyses. Analyses of variance (ANOVA) and means separation using Fisher's protected least significant difference $(P<$ 0.05 ) were performed on dependent variables using PROC GLM of SAS (version 9.2; SAS Institute, Cary, NC). Data were subjected to logarithmic, square root, or arcsine square root transformations when assumptions of homogeneous variances and/or normally distributed residuals were not met, or to Friedman's nonparametric rank test if transformations did not resolve violations of these assumptions.

\section{Results}

Spinach wilt and plant growth assessment. Fusarium wilt was observed in both the 2009 and 2012 trials. The incidence of wilt increased throughout each season, from $2.0 \pm 0.2 \%$ (mean \pm standard error across all treatments) on 15 May 2009 to $90.8 \pm 1.6 \%$ on 14 July 2009 , and from $2.1 \pm 0.2 \%$ on 29 May 2012 to $100 \%$ on 31 July 2012. In 2009, spinach plants in plots in the replication closest to the edge of the field had markedly less wilt than plants in the other four replications, regardless of treatments. Therefore, data collected from plots in this replication were not included in the statistical analyses because the very low level of disease suggested that portion of the field was not planted in the 2005 spinach seed crop. In 2009, the mean daily temperature and total rainfall for April, May, June, July, and August were $8.8^{\circ} \mathrm{C}$ and $4.3 \mathrm{~cm}, 12.0^{\circ} \mathrm{C}$ and $2.6 \mathrm{~cm}, 15.6^{\circ} \mathrm{C}$ and $0.4 \mathrm{~cm}, 17.9^{\circ} \mathrm{C}$ and $1.3 \mathrm{~cm}$, and $16.5^{\circ} \mathrm{C}$ and $1.3 \mathrm{~cm}$, respectively. That trial was irrigated with $3.3 \mathrm{~cm}$ of water on 18 June. In 2012, the mean daily temperature and total rainfall for April, May, June, July, and August were $9.9^{\circ} \mathrm{C}$ and $11.0 \mathrm{~cm}, 11.8^{\circ} \mathrm{C}$ and $6.1 \mathrm{~cm}, 13.4^{\circ} \mathrm{C}$ and $8.0 \mathrm{~cm}, 15.9^{\circ} \mathrm{C}$ and $3.3 \mathrm{~cm}$, and $17.1^{\circ} \mathrm{C}$ and $0.03 \mathrm{~cm}$, respectively.

In 2009, the main effect of rate of limestone application on wilt incidence was not significant on 15 May $(P=0.8232)$, when wilt incidence averaged $2.0 \%$, or 4 June $(P=0.1099)$, when wilt averaged $4.0 \%$, but was significant by 24 June $(P=0.0381)$, when plots amended with limestone at $4.48 \mathrm{t} / \mathrm{ha}$ had fewer wilted plants $(5.3 \pm$ $0.9 \%)$ than plots at $2.24 \mathrm{t} / \mathrm{ha}(12.9 \pm 3.3 \%)$ or $0 \mathrm{t} / \mathrm{ha}(33.6 \pm 6.7 \%)$, averaged across all three spinach parent lines and both $\mathrm{N}$ treatments (Supplementary Table S1; Fig. 2A). On 24 June, all three female spinach lines showed a similar decrease in incidence of wilted plants with increasing rate of limestone amendment (Fig. 3B). By 14 July, incidence of wilt averaged 89.1 to $92.0 \%$ for all limestone treatments, with no significant main effect of limestone treatments $(P=0.5556$; Figs. 2A and 3C).

In 2012, the main effect of limestone amendment was not significant on 29 May $(P=0.2225)$, when wilt incidence was $<2.1 \%$, or on 19 June $(P=0.1534)$, when wilt incidence averaged $18.5 \%$, but was significant by 9 July $(P=0.0001)$, when an average $87.7 \%$ of the plants were wilting (Fig. 2B). At the latter two ratings, the effects of limestone varied depending on spinach inbred line $(P=0.0233$ and 0.0002 for the limestone-inbred line interaction term on 19 June and 9 July, respectively, in the ANOVA; Fig. 3E and F). On 19 June, there were significant differences in wilt incidence among limestone treatments for the susceptible female line only, with less wilt in the
0/4.48 t/ha and the $4.48 \mathrm{t} / \mathrm{ha} /$ year plots compared with the 0 and 2.24 t/ha/year plots (Supplementary Table S2; Fig. 3E). On 9 July, wilt incidence was so great for the susceptible female line and the male line that no significant effects of limestone treatment were observed whereas, for the moderate and resistant female lines, the $4.48 \mathrm{t} / \mathrm{ha}$ /year plots had the least wilt, followed in order of increasing wilt by plots with limestone at $2.24 \mathrm{t} / \mathrm{ha} /$ year, $0 / 4.48 \mathrm{t} / \mathrm{ha}$, and $0 \mathrm{t} / \mathrm{ha} /$ year (Fig. 3F). For the moderate female, wilt incidence associated with the latter two limestone treatments were not significantly different.

Wilt severity, which was rated in addition to wilt incidence on 9 and 31 July 2012, was affected significantly by rate of limestone amendment $(P=0.0003$ and 0.0004 , respectively). On 9 July, wilt severity was greatest in the $0 \mathrm{t} / \mathrm{ha} /$ year and $0 / 4.48 \mathrm{t} /$ ha plots $(2.58 \pm 0.18$ and $2.26 \pm 0.17$, respectively; Fig. 4A). Wilt in plots amended with limestone at $2.24 \mathrm{t} / \mathrm{ha} /$ year $(2.07 \pm 0.18)$ was more severe than in the 4.48 $\mathrm{t} /$ ha/year plots $(1.66 \pm 0.22)$. Wilt severity in the $0 / 4.48 \mathrm{t} / \mathrm{ha}$ plots on this date was not different from that of the 0 or $2.24 \mathrm{t} / \mathrm{ha} / \mathrm{year}$ plots but was more severe than in the $4.48 \mathrm{t} / \mathrm{ha} /$ year plots. By $31 \mathrm{July}$, wilt was more severe in the 0 and $0 / 4.48 \mathrm{t} /$ ha plots compared with the 2.24 and $4.48 \mathrm{t} / \mathrm{ha} /$ year plots $(3.63 \pm 0.16$ and $3.47 \pm 0.16$ versus $3.27 \pm$ 0.14 and $3.14 \pm 0.15$, respectively; Fig. 4B).

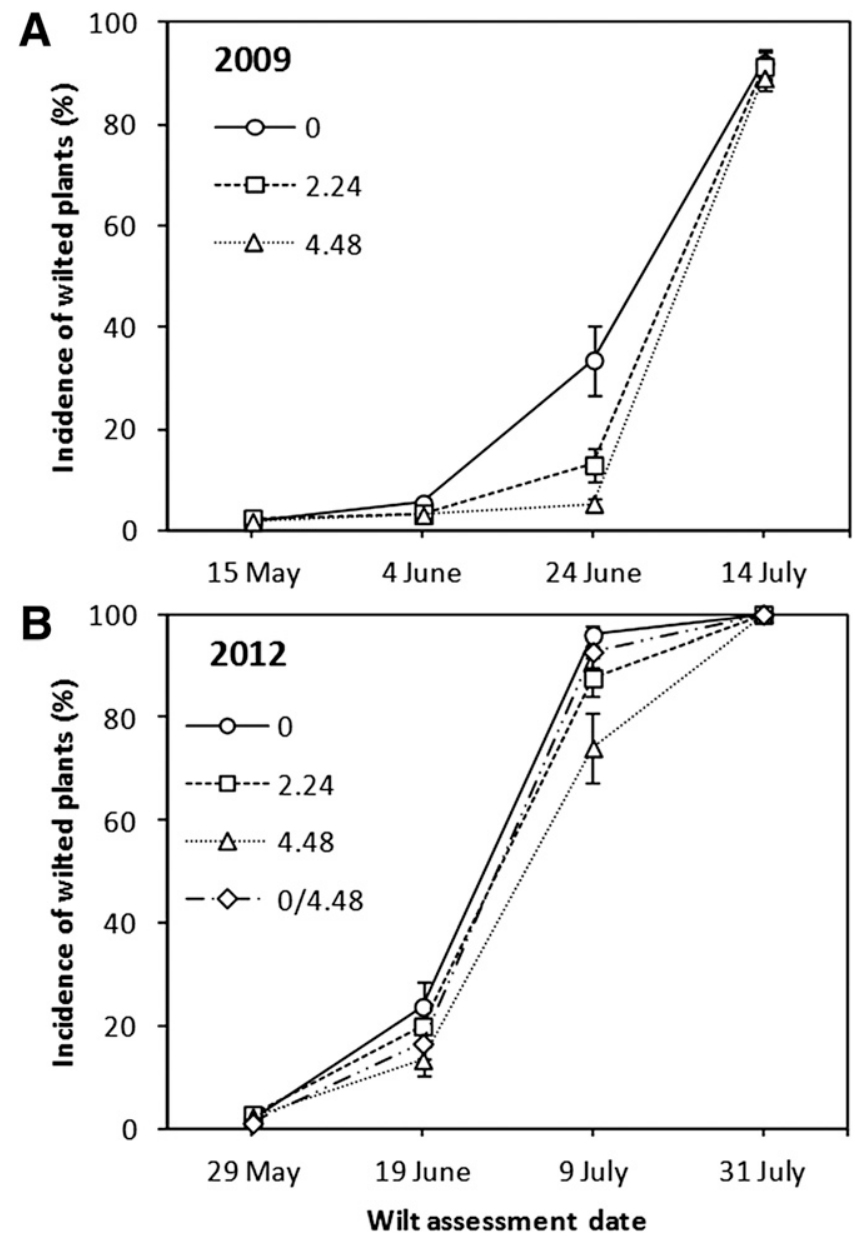

Fig. 2. Influence of agricultural limestone application rate on incidence of Fusarium wilt in A, 2009 and B, 2012 spinach seed crop field trials. Witt incidence was measured as the percentage of plants with wilt symptoms in $3 \mathrm{~m}$ of the center two rows per plot, averaged over four (2009) or five (2012) replications. For 2009, each data point is the mean and standard error of 32 (15 May and 4 June) or 24 (24 June and 14 July) observations. In 2012, each data point is the mean and standard error of 20 observations. Limestone amendment rates were $0,2.24$, and 4.48 tha/year from 2009 to 2011. In the 2012 spinach seed crop trial, a fourth limestone treatment was added in which the control plots that had received no limestone from 2009 to 2011 were divided in half, with one half again receiving no limestone and the other half amended with limestone at 4.48 tha (the $0 / 4.48$ treatment) prior to planting the spinach trial. 
In the 2009 trial, F. oxysporum was isolated from all 10 wilted seedlings of each female spinach line and from 9 of 10 seedlings of the male line (no other fungal seedling pathogens were detected). In the 2012 trial, two wilted seedlings collected from each of the susceptible and moderate female lines were colonized by $F$. oxysporum, and no other known spinach pathogens were isolated. Of two wilted seedlings collected from plots of the resistant female, one was colonized by $F$. oxysporum, and the other by a Rhizoctonia sp. F. oxysporum isolates also were obtained from four healthy seedlings, one from each inbred line. In addition, a species of Rhizoctonia was isolated from a moderate female seedling. The $F$. oxysporum isolates were not tested for pathogenicity on spinach to determine whether they were $F$. oxysporum f. sp. spinaciae isolates.

In both the 2009 and 2012 trials, the limestone treatments had a significant effect on incidence of vascular discoloration $(P=0.0082$ and 0.0367 , respectively), spinach biomass $(P=0.0024$ on 29 June
2009, $P=0.0165$ on 22 July 2009 , and $P<0.0001$ on 11 July 2012), and seed yield $(P=0.0320$ and $P<0.0001$ in 2009 and 2012, respectively; Figs. 5 and 6). In 2009, more plants in the 0 and 2.24 t/ha plots had vascular discoloration compared with plants in the 4.48 t/ha plots $(98.3 \pm 1.2$ and $97.1 \pm 2.1 \%$ versus $91.0 \pm 3.1 \%)$. Conversely, in 2012 , fewer spinach plants in the 0 t/ha/year plots had vascular discoloration $(70.7 \pm 6.4 \%)$ compared with plants in the $0 / 4.48 \mathrm{t} /$ ha plots $(87.0 \pm$ $3.5 \%)$ but not compared with the 2.24 or $4.48 \mathrm{t} / \mathrm{ha} /$ year plots $(83.4 \pm 3.7$ and $77.4 \pm 4.5 \%$, respectively). On 29 June 2009 , dry spinach biomass was greater in the $4.48 \mathrm{t} / \mathrm{ha}$ plots $(124.3 \mathrm{~g} / \mathrm{m}$ of row) compared with the $2.24 \mathrm{t} / \mathrm{ha}$ plots $(95.0 \mathrm{~g} / \mathrm{m}$ of row) which, in turn, produced more spinach biomass than the 0 t/ha plots $(60.6 \mathrm{~g} / \mathrm{m}$ of row) (Fig. 5A). When biomass was assessed again on 22 July 2009 , spinach plants were significantly smaller in plots with no limestone $(83.2 \mathrm{~g} / \mathrm{m}$ of row $)$ versus plots with limestone at 2.24 or $4.48 \mathrm{t} / \mathrm{ha}$ (129.7 to $153.7 \mathrm{~g} / \mathrm{m}$ of row, respectively; Fig. 5B). For the biomass assessment on 11 July 2012, plots
A

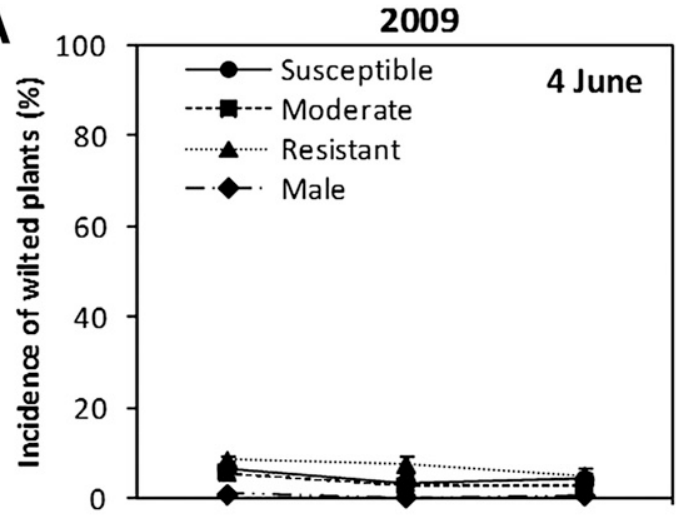

B
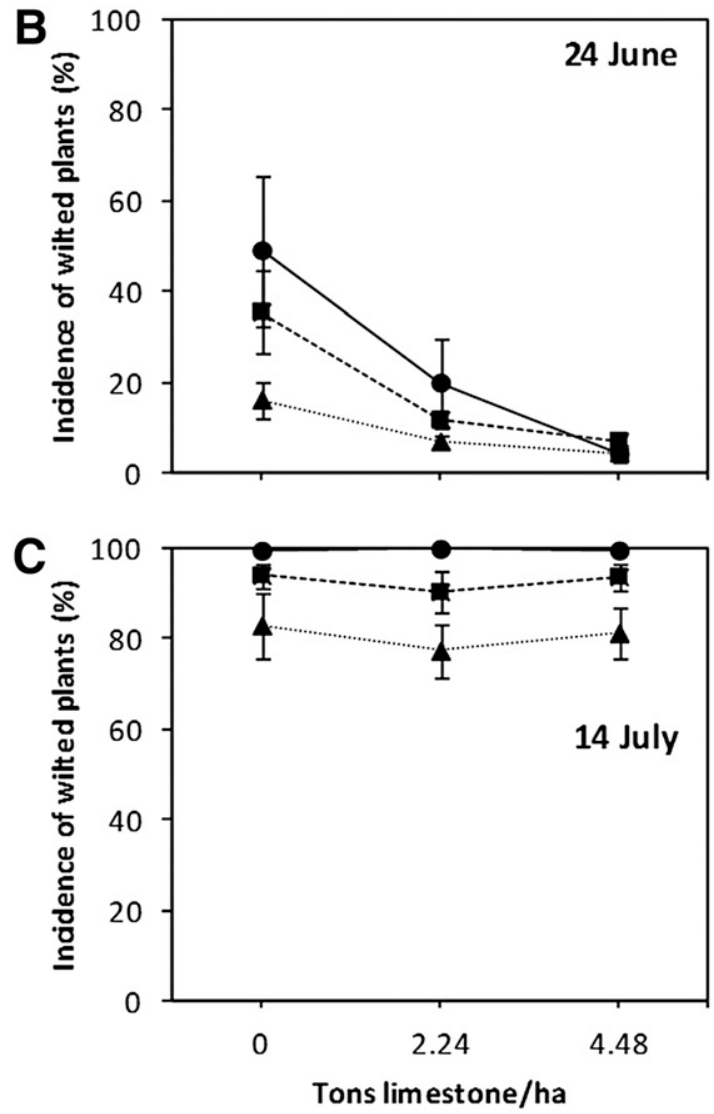

D

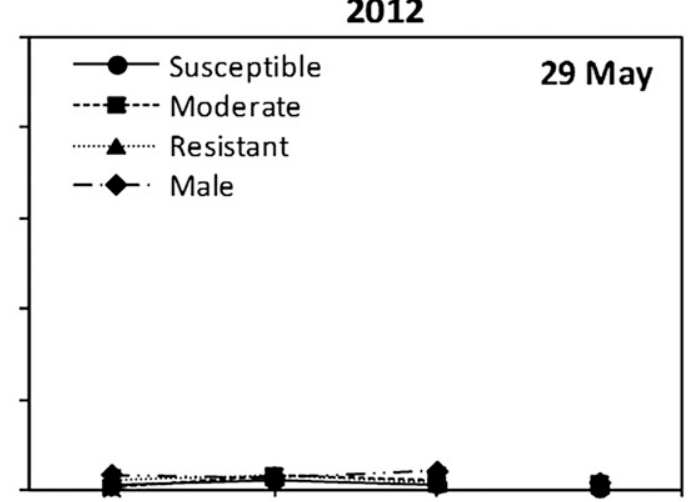

E

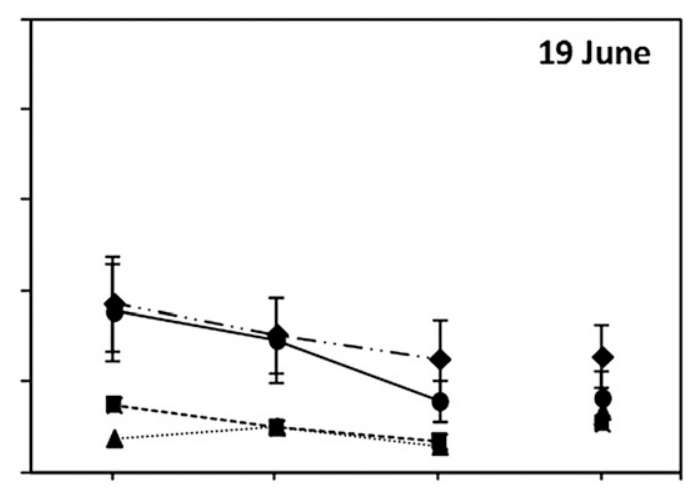

$\mathbf{F}$

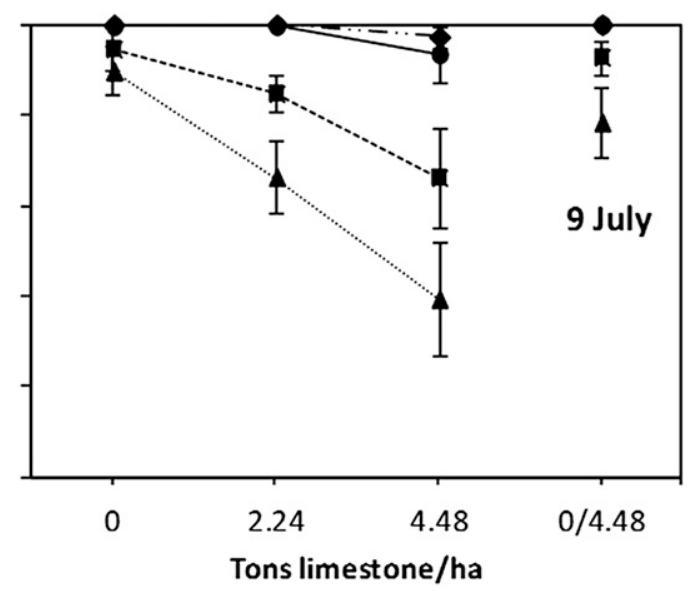

Fig. 3. Influence of limestone application rate and susceptibility of spinach inbred lines to Fusarium wilt on the incidence of wilt in A, B, and C, 2009 and D, E, and F, 2012 spinach seed crop field trials. Wilt incidence was measured as the percentage of plants with wilt symptoms in $3 \mathrm{~m}$ of the center two rows per plot, averaged over four (2009) or five (2012) replications. Each data point is the mean and standard error of eight (2009) or five (2012) observations. Limestone amendment rates were $0,2.24$, and 4.48 t/ha/year from 2009 to 2011. In the 2012 trial, a fourth limestone treatment was added in which the control plots that received no limestone from 2009 to 2011 were divided in half, with one half again receiving no limestone and the other half amended with limestone at 4.48 t/ha (the 0/4.48 treatment) prior to planting the spinach trial. 
that received limestone at $4.48 \mathrm{t} / \mathrm{ha}$ for 4 years yielded larger spinach plants $(221.8 \mathrm{~g} / \mathrm{m}$ of row $)$ than plots that received a single application of $4.48 \mathrm{t} / \mathrm{ha}$ just prior to planting $(167.0 \mathrm{~g} / \mathrm{m}$ of row) which, in turn, had larger plants than plots that received $0 \mathrm{t} / \mathrm{ha}$ /year throughout the 4-year trial (114.1 g/m of row; Fig. 5C).

In the 2009 trial, plots treated with limestone at $4.48 \mathrm{t} / \mathrm{ha}$ had greater marketable spinach seed yield $(554 \mathrm{~kg} / \mathrm{ha})$ than the $0 \mathrm{t} / \mathrm{ha}$ plots (206 kg/ha; Fig. 6A). In the 2012 trial, seed yield was significantly different among all four limestone treatments, with $0 \mathrm{t} / \mathrm{ha} / \mathrm{year}$ plots yielding the least seed $(407 \mathrm{~kg} / \mathrm{ha})$, followed by the $0 / 4.48 \mathrm{t} / \mathrm{ha}$ plots (702 kg/ha), $2.24 \mathrm{t} / \mathrm{ha} /$ year plots $(920 \mathrm{~kg} / \mathrm{ha})$, and $4.48 \mathrm{t} / \mathrm{ha} /$ year plots (1,018 kg/ha) (Fig. 6D). For the susceptible female inbred line, seed yield in plots with $0 \mathrm{t} / \mathrm{ha} /$ year and $0 / 4.48 \mathrm{t} / \mathrm{ha}$ were not different. Common scab, caused by $S$. scabies, was not observed on any of the potato tubers harvested in 2010, and there were no significant effects of limestone treatment on potato yield or incidence of other tuber diseases (data not shown).

The effects of spinach parent line susceptibility to Fusarium wilt on wilt incidence, spinach biomass production, vascular discoloration, and seed yield were significant in both the 2009 and 2012 trials, although not at each evaluation date in 2009. In 2009, spinach inbred lines did not affect wilt incidence significantly at the first rating on 15 May $(P=0.5409)$ when wilt incidence was very low $(<3 \%)$. However, by 4 June, the susceptible and resistant inbreds had significantly more damping-off or wilt (4.7 and $7.0 \%$, respectively) than the male line $(0.6 \%)(P=0.0014$; Fig. 3A), suggesting the presence of other damping-off or wilt pathogens such as Rhizoctonia spp. By 24 June, there was a notable but not significant trend toward decreasing wilt with increasing level of Fusarium wilt resistance in the spinach parent lines $(P=0.1596$; Fig. 3B $)$. By the final wilt assessment on 14 July, there were significant differences among the three female inbred lines $(P<0.0001)$, with the least wilt in plots with the resistant female $(80.4 \%)$ and the most wilted plants in plots of the susceptible female (99.5\%; Fig. 3C). In the 2012 trial, more male plants were wilting than the three female inbreds at the first rating when wilt incidence averaged $<3 \%(P=0.0133)$. On 19 June 2012, more wilted plants were observed in plots of the susceptible female line and the male line compared with the moderate and resistant female lines (24.3 and $29.6 \%$ versus 10.7 and $9.4 \%$, respectively, $P=0.0028$; Fig. 3D and E). By 9 July 2012, the susceptible female line and the male line had 98.3 and $99.3 \%$ wilt incidence, respectively, whereas the moderate female averaged $84.6 \%$ wilt incidence and the resistant female only $68.5 \%(P<$ $0.0001)$.

Because these trials were within pollination distance of a nearby commercial spinach seed field each year, it was necessary to plant seed of the male line planted in the closest commercial spinach seed crop. Consequently, the male line used in 2012 was not the same male line used in the 2009 trial. The 2012 male line bolted and senesced later but was more susceptible to Fusarium wilt than the 2009 male line. By 9 July 2012, wilt was most severe in the male line (2.98), followed by the susceptible, moderate, and resistant female inbred lines $(P<0.0001)$ in decreasing order of Fusarium wilt severity $(2.62$, 1.76 , and 1.22 , respectively) (Fig. 4A). By the final wilt severity rating on 31 July 2012, the male line had senesced and could not be rated.

In the 2009 trial, the susceptible female inbred had 100\% incidence of vascular discoloration typical of Fusarium wilt on 22 July, which was greater than that of the moderate and resistant female lines ( 94.0 and $92.5 \%$, respectively, $P=0.0251$ ). Similarly, the susceptible female and male lines had more vascular discoloration (96.2 and $95.1 \%)$ than the moderate and resistant female lines (69.4 and $57.7 \%$ ) in the 2012 trial, with the latter having the lowest incidence of vascular discoloration $(P<0.0001)$.

On 29 June 2009, the male and susceptible female lines had significantly more biomass $(P=0.0002)$ than the moderate female $(113.9$ and 97.6 versus $89.9 \mathrm{~g} / \mathrm{m}$ of row) which, in turn, had more biomass than the resistant female $(71.7 \mathrm{~g} / \mathrm{m}$ of row $)$, reflecting the genetically predetermined smaller phenotype of the resistant female inbred compared with the other inbreds (Fig. 5A). By 22 July 2009, however, there were no significant differences in biomass among inbred lines $(P=0.1659)$, suggesting that the reduced level of wilt in the resistant female eventually compensated for the size differential (Fig. 5B). In the 2012 trial, the susceptible and moderate inbreds had greater biomass $(P=0.0130)$ than the resistant and male lines $(183.1$ and 185.5 versus 161.8 and $166.6 \mathrm{~g} / \mathrm{m}$ of row, respectively), regardless of limestone application rate (Fig. 5C). Despite the smaller size of the resistant female line, the moderate and resistant inbreds had 62 and $50 \%$ greater marketable seed yield, respectively, than the susceptible inbred in the 2009 trial $(P=0.0332 ;$ Fig. 6A). In the 2012 trial, differences in seed yield were more pronounced $(P<0.0001)$, with the resistant inbred yielding $171 \%$ more marketable seed than the susceptible inbred and $55 \%$ more than the moderate female inbred (Fig. 6D).

Rainfall $(2.5 \mathrm{~cm}) 10$ days after planting the 2009 trial caused severe leaching of nitrate in plots fertilized in-furrow with $\mathrm{NO}_{3}{ }^{-}-\mathrm{N}$ fertilizer. Unlike $\mathrm{NH}_{4}{ }^{+}$cations, $\mathrm{NO}_{3}{ }^{-}$anions are not retained by the CEC of soils, and are susceptible to leaching (Havlin et al. 1999). As a result, spinach plants in plots fertilized with $\mathrm{NO}_{3}{ }^{-}-\mathrm{N}$ expressed severe chlorosis and stunting throughout the 2009 trial, and were outyielded $(P=0.0095)$ by $\mathrm{NH}_{4}{ }^{+}-\mathrm{N}$ fertilized plots by $83 \%$. However, early in the 2009 season (4 June), plants of the moderate female line had significantly less wilt in $\mathrm{NO}_{3}{ }^{-}$-fertilized plots compared with $\mathrm{NH}_{4}{ }^{+}$-fertilized plots $(P=0.0187$ for the inbred line- $\mathrm{N}$ fertilizer interaction term). Similarly, the moderate female had more vascular discoloration in plots fertilized with $\mathrm{NH}_{4}{ }^{+}-\mathrm{N}$ versus $\mathrm{NO}_{3}{ }^{-}-\mathrm{N}$
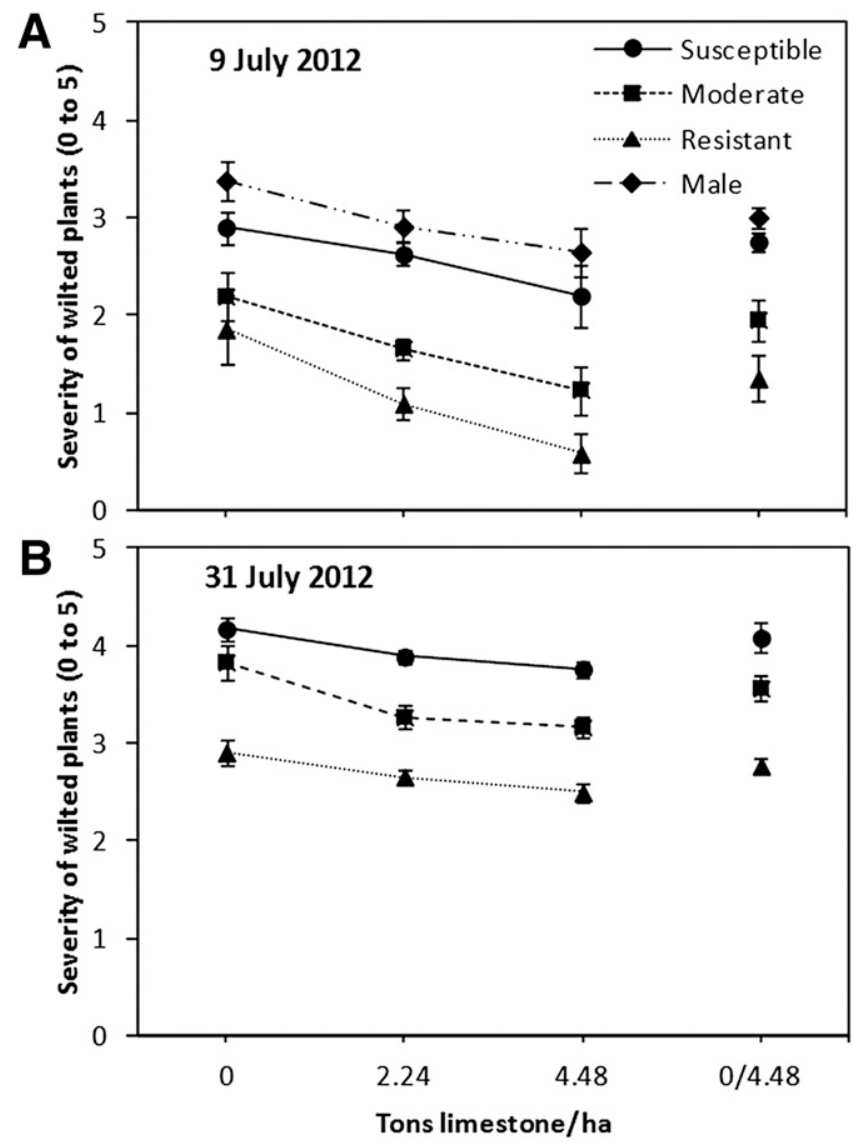

Fig. 4. Influence of limestone application rate and susceptibility of spinach inbred lines to Fusarium wilt on the severity of wilt in a spinach seed crop trial on A, 9 July and B, 31 July 2012. Wilt severity of each plant in $3 \mathrm{~m}$ of the center two rows per plot was measured using a 0 -to- 5 rating scale, where $0=$ healthy plant and $5=$ plant dead due to wilt. Each data point is the mean and standard error of five replicate plots. The male spinach line had senesced by 31 July and, therefore, was excluded from wilt rating. Limestone application rates of $0,2.24$, and 4.48 tha/year were applied to the same plots each season from 2009 to 2011. In 2012, a fourth limestone treatment was added in which the control plots that had received no limestone from 2009 to 2011 were divided in half, with one half again receiving no limestone and the other half amended with limestone at 4.48 tha (the 0/4.48 treatment) prior to planting the spinach trial. 
$(P=0.0429$ for the inbred line $-\mathrm{N}$ fertilizer interaction term), whereas fertilizer did not affect vascular discoloration of the other two female lines (data not shown). By 14 July, plants in plots fertilized with $\mathrm{NO}_{3}{ }^{-}-\mathrm{N}$ had significantly more wilt than plants in plots fertilized with $\mathrm{NH}_{4}{ }^{+}-\mathrm{N}$ for the susceptible and resistant lines, and there was no significant effect of fertilizer on wilt incidence for the moderate parent $(P=0.0046$ for the inbred line-N fertilizer interaction term). Spinach biomass on 29 June was greater in plots fertilized with $\mathrm{NH}_{4}{ }^{+}-\mathrm{N}$ versus $\mathrm{NO}_{3}{ }^{-}-\mathrm{N}$ for the susceptible female and male lines but not for the moderate or resistant female lines $(P=0.0143$ for the inbred line- $\mathrm{N}$ fertilizer interaction term).

The effects of $\mathrm{N}$ fertilizer treatment were also influenced by rate of limestone amendment for two of the variables measured in 2009. In plots with limestone at 0 and $2.24 \mathrm{t} / \mathrm{ha}, \mathrm{NO}_{3}{ }^{-}-\mathrm{N}$ fertilizer significantly increased wilt incidence compared with $\mathrm{NH}_{4}{ }^{+} \mathrm{N}$ on 24 June $(P=0.0191$ for the limestone-N fertilizer interaction term) but the fertilizers had no significant effect in plots with limestone at $4.48 \mathrm{t} / \mathrm{ha}$. Similarly, spinach biomass on 29 June was not affected by $\mathrm{N}$-fertilizer in plots with limestone at $4.48 \mathrm{t} / \mathrm{ha}$ but biomass was greater with $\mathrm{NH}_{4}{ }^{+}-\mathrm{N}$ versus $\mathrm{NO}_{3}{ }^{-}-\mathrm{N}$ fertilization in plots with limestone at 0 or $2.24 \mathrm{t} / \mathrm{ha}(P=0.0146$ for the limestone-N fertilizer interaction term).

Seed germination and health assays. There were no significant effects of limestone application rate on seed germination or incidence of necrotrophic fungi found on seed harvested in the 2009 trial (data not shown). However, in the 2012 trial, the 4 years of annual limestone treatments resulted in significant effects on the incidence of seedborne $V$. dahliae $(P<0.0001)$ and Alternaria spp.
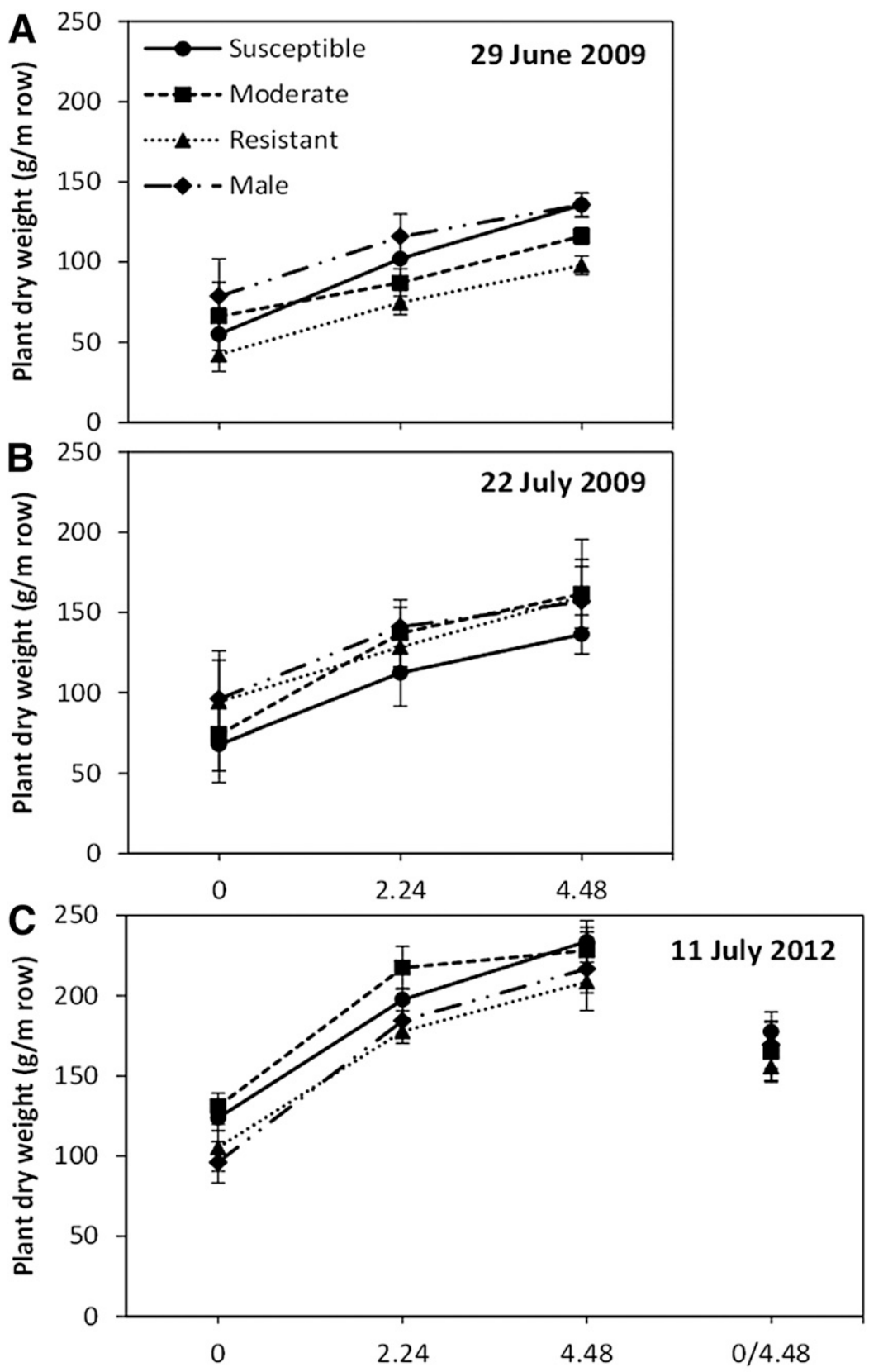

Tons limestone/ha

Fig. 5. Influence of limestone application rate and susceptibility of spinach inbred lines to Fusarium wilt on dried spinach plant biomass in a spinach seed crop trial in 2009 and 2012. Biomass was measured by drying and weighing plants in $1 \mathrm{~m}$ of row per plot. In 2009, biomass was measured on A, 29 June and B, 22 July. In 2012, biomass was measured on C, 11 July. Each data point represents the mean and standard error of eight (2009) or five (2012) replicate plots. Limestone amendment rates were 0, 2.24, and 4.48 t/ha from 2009 to 2011. In the 2012 spinach seed crop trial, a fourth limestone treatment was added in which the control plots that had received no limestone from 2009 to 2011 were divided in half, with one half again receiving no limestone and the other half amended with limestone at 4.48 tha (the 0/4.48 treatment) prior to planting the spinach trial. 
$(P=0.0059)$ (Supplementary Table S3). Seed harvested from plots that received limestone at $4.48 \mathrm{t} / \mathrm{ha}$ for each of 4 years had significantly more $V$. dahliae (11.5\%) compared with seed harvested from the $2.24 \mathrm{t} / \mathrm{ha} /$ year plots and the $0 / 4.48 \mathrm{t} / \mathrm{ha}$ plots (5.6 and $3.2 \%$ ) which, in turn, had significantly more $V$. dahliae than seed from the 0 t/ha/year plots $(0.9 \%$ ) (Fig. 6E). Fewer seed from the $4.48 \mathrm{t} /$ ha/year plots were infested with Alternaria spp. (33\%) compared with seed from the $0 \mathrm{t} / \mathrm{ha} /$ year plots $(45.5 \%)$ and $0 / 4.48 \mathrm{t} / \mathrm{ha}$ plots $(46.1 \%)$.

The main effect of female spinach inbred line on the incidence of rotten seed $(P=0.0022)$ and the incidences of seed infested with Fusarium spp. and Stemphylium botryosum $(P=0.0185$ and 0.0118 , respectively) were significant in the 2009 trial. More seed harvested from the susceptible female were rotten (20.0\%) compared with seed of the moderate and resistant female lines (8.3 and $7.4 \%$, respectively), and more of the susceptible female seed was infested with Fusarium spp. than the moderate or resistant female seed (4.2 versus 0.9 and $0.7 \%$, respectively) (Fig. 6C). More seed of the moderate female was infested with $S$. botryosum $(7.4 \%)$ compared with seed of the susceptible (3.2\%) and resistant females $(3.3 \%)$. In the 2012 trial, spinach parent line significantly affected the incidence of germinated $(P=0.0134)$, nongerminated $(P=0.0188)$, and rotten $(P<0.0001)$ seed, as well the percentage of seed on which Fusarium spp. $(P<0.0001), V$. dahliae $(P=0.0071)$, and Alternaria spp. $(P=$ $0.0014)$ were detected. The percentage of rotten seed harvested from the susceptible female $(32.6 \%)$ was greater than that of seed harvested from the moderate female $(20.5 \%)$, which was greater than that of seed harvested from the resistant female (6.3\%). The percentage of viable (germinated) seed was greatest for seed harvested from the resistant and moderate females (67.0 and 61.5\%, respectively) compared with seed from the susceptible female (50.8\%). However,
A

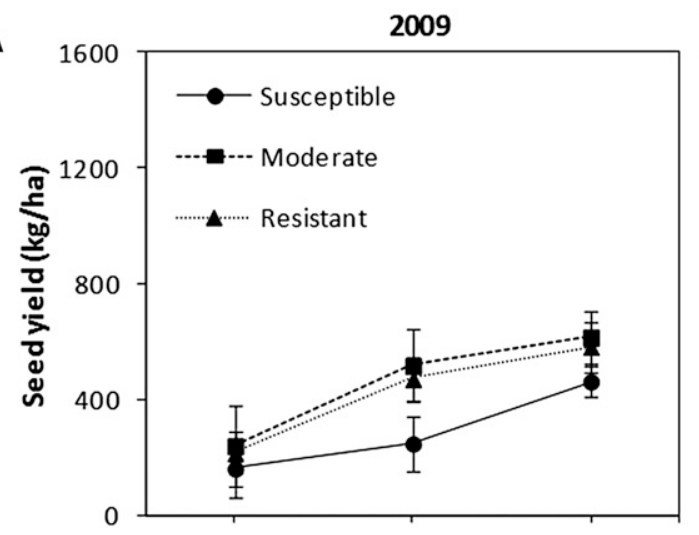

B
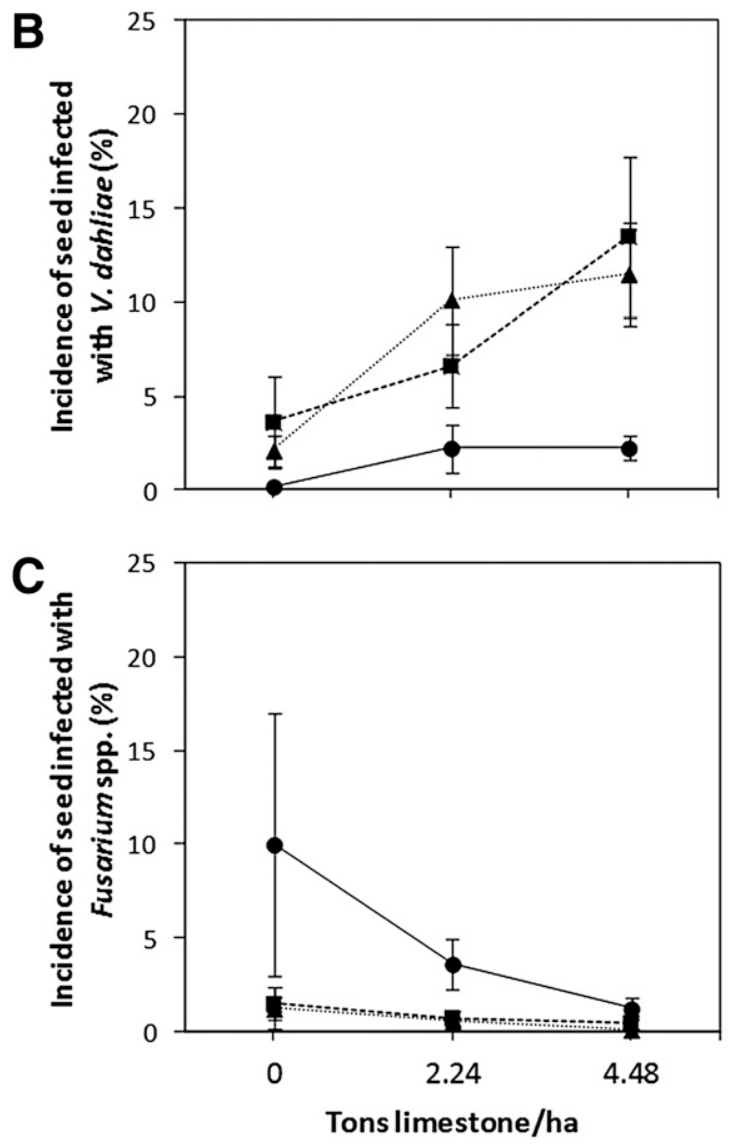

D

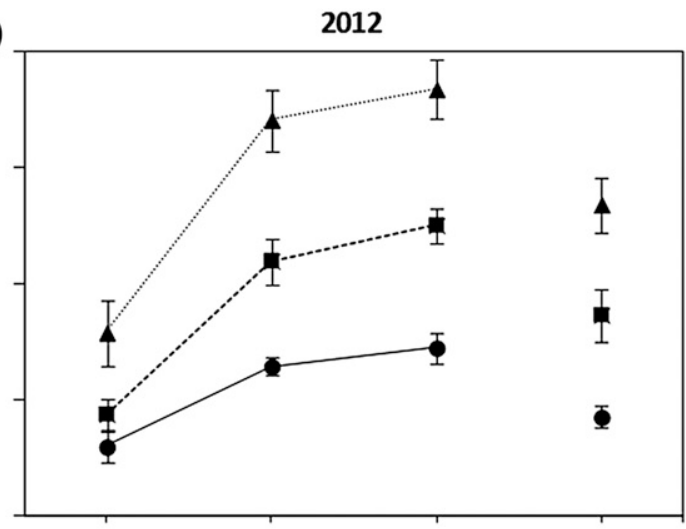

$\mathbf{E}$

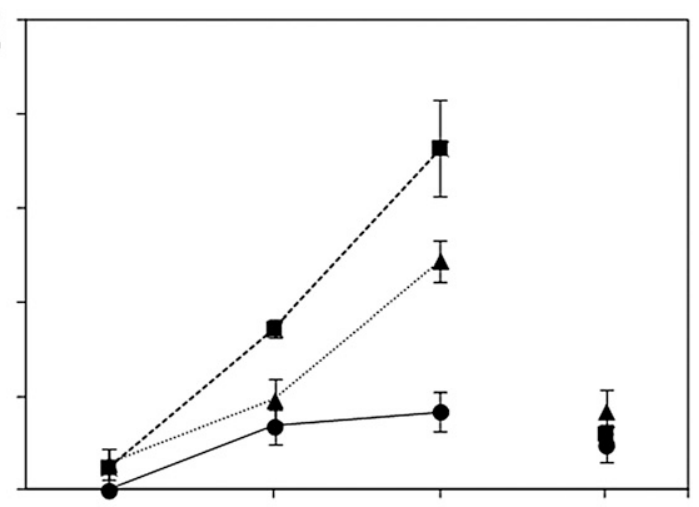

$\mathbf{F}$

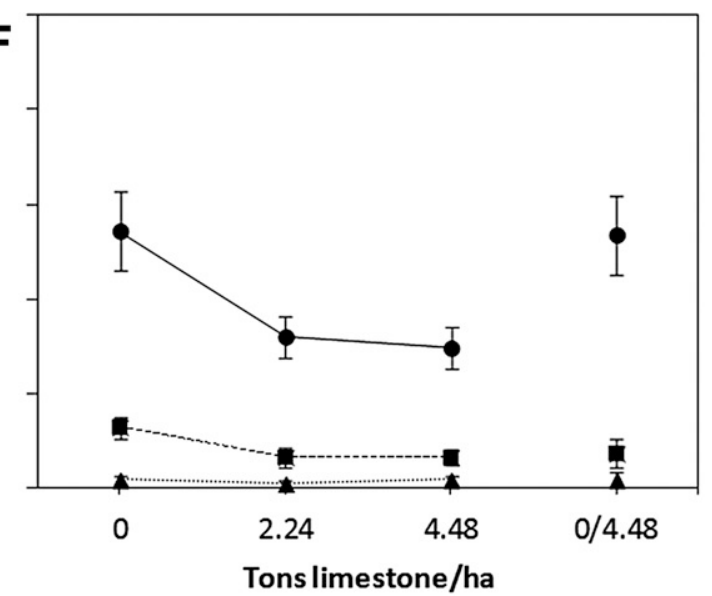

Fig. 6. Influence of limestone application rate and susceptibility of three female spinach inbred lines to Fusarium wilt on $\mathbf{A}$ and $\mathbf{D}$, marketable spinach seed yield; $\mathbf{B}$ and $\mathbf{E}$, incidence of seed infected with Verticillium dahliae; and C and F, incidence of seed infected with Fusarium spp. in spinach seed crop trials in 2009 (A, B, and C) and 2012 (D, E, and F). Each data point represents the mean and standard error of eight (2009) or five (2012) plots. Limestone application rates of $0,2.24$, and 4.48 t/ha were applied to the same plots each season from 2009 to 2011. In the 2012 spinach seed crop trial, a fourth limestone treatment was added in which the control plots that had received no limestone from 2009 to 2011 were divided in half, with one half again receiving no limestone and the other half amended with limestone at 4.48 t/ha (the $0 / 4.48$ treatment) prior to planting the spinach trial. 
the incidence of dormant seed was greater for seed harvested from the resistant female $(26.2 \%)$ versus the susceptible and moderate females (15.7 and $17.2 \%$, respectively). More seed of the susceptible female was infected with Fusarium spp. (10.6\%) compared with seed of the moderate female $(2.1 \%)$ which, in turn, had more seed infected with Fusarium spp. than the resistant female (0.4\%) (Fig. 6F). The reverse was observed for $V$. dahliae seed infection. More seed of the resistant and moderate female lines was infected with this fungal pathogen (5.7 and 7.8\%, respectively) compared with seed of the susceptible female $(2.5 \%)$ (Fig. 6E). The amount of seed of the moderate and resistant inbred lines infected with $V$. dahliae increased with increasing limestone rate $(P=0.0136$ for the limestone-inbred female line interaction term), from 1.2 to $18.2 \%$ for the moderate female and 1.4 to $12.2 \%$ for the resistant female. For the susceptible female inbred, there were no significant differences in $V$. dahliae seed infection levels among plots amended with limestone at $0 / 4.48,2.24$, and $4.48 \mathrm{t} / \mathrm{ha}$ but plots with $0 \mathrm{t} / \mathrm{ha} /$ year had $0 \%$ seed infected with $V$. dahliae. Fewer seed of the susceptible female were infested with Alternaria spp. than seed of the moderate and resistant females, which did not differ significantly.

In 2009, the effects of fertilizer $\mathrm{N}$ form were significant for the incidence of germinated, nongerminated, and rotten seed but not for the incidence of seed-associated necrotrophic fungi (data not shown). Seed harvested from plots fertilized with $\mathrm{NO}_{3}{ }^{-}-\mathrm{N}$ were of poorer quality than seed harvested from plots fertilized with $\mathrm{NH}_{4}{ }^{+}-\mathrm{N}$, as demonstrated by a lower germination rate (58.9 versus $83.2 \%$, respectively), as well as greater incidences of rotten seed (16.6 versus $7.4 \%$, respectively) and nongerminated (dormant) seed (16.4 versus $5.3 \%$, respectively).

Plant nutrient analyses. In the 2009 trial, increasing limestone application rate significantly increased plant $\mathrm{P}(P=0.0004), \mathrm{Ca}$ $(P=0.0028)$, and $\mathrm{S}(P=0.0019)$ and significantly decreased plant $\mathrm{Mg}(P=0.0025), \mathrm{Zn}(P=0.0211)$, and Mn $(P=0.0457)$ (Supplementary Table $S 4)$. Spinach inbred lines had a significant effect on all plant nutrients measured, with most nutrients less concentrated in the susceptible female line; and $\mathrm{N}$ fertilizer treatments affected all plant nutrients, except $\mathrm{Ca}, \mathrm{Mn}$, and $\mathrm{Fe}$. The effects of limestone rate on plant $\mathrm{Mg}$ and $\mathrm{Mn}$ were influenced by $\mathrm{N}$ fertilizer $(P=0.0219$ and 0.0167 , respectively, for the interaction term), and the effect of limestone on plant $\mathrm{N}$ was influenced by both $\mathrm{N}$ fertilizer and inbred line $(P=0.0179$ for the three-way interaction). In plots amended with limestone at 2.24 and $4.48 \mathrm{t} / \mathrm{ha}$, spinach plants had more concentrated $\mathrm{Ca}$ (1.27 and $1.37 \%$, respectively) than plants in 0 t/ha plots $(1.07 \%)$. Conversely, plant levels of $\mathrm{Zn}$ and $\mathrm{Mn}$ were greater in the $0 \mathrm{t} / \mathrm{ha}$ plots
(117.2 and $178.2 \mathrm{mg} / \mathrm{kg}$, respectively) compared with the $4.48 \mathrm{t} / \mathrm{ha}$ plots (97.1 and $33.8 \mathrm{mg} / \mathrm{kg}$, respectively) and compared with $2.24 \mathrm{t} / \mathrm{ha}$ plots for Mn $(143.0 \mathrm{mg} / \mathrm{kg})$.

In the 2012 trial, there were significant main effects of limestone application rate on spinach plant levels of $\mathrm{Mg}(P=0.0096), \mathrm{B}(P=$ $0.0105), \mathrm{Zn}(P=0.0033)$, and $\mathrm{Mn}(P=0.0012)$, with the most concentrated levels of these nutrients in plants growing in $0 \mathrm{t} / \mathrm{ha} / \mathrm{year}$ plots and the least concentrated in the 2.24 to $4.48 \mathrm{t} / \mathrm{ha} /$ year plots. The concentration of $\mathrm{Zn}$ and $\mathrm{Mn}$ decreased by 40.8 and $66.1 \%$, respectively, in plants growing in the $4.48 \mathrm{t} / \mathrm{ha} /$ year plots compared with the $0 \mathrm{t} / \mathrm{ha} /$ year plots. Ca was less concentrated in spinach plants growing in $0 \mathrm{t} / \mathrm{ha}$ /year plots compared with 2.24 and $4.48 \mathrm{t} / \mathrm{ha} /$ year plots of the susceptible inbred (0.93 versus 1.31 and $1.27 \%$, respectively) and resistant ( 0.95 versus 1.21 and $1.32 \%$, respectively) female inbred lines $(P=0.0056$ for the limestone-inbred interaction term). Only spinach $\mathrm{N}$ levels were affected significantly by inbred line $(P=0.0149)$. The limestone-inbred interaction was significant $(P=0.0056)$ for spinach $\mathrm{Ca}$, with the least concentrated $\mathrm{Ca}$ detected in the $0 \mathrm{t} / \mathrm{ha} / \mathrm{year}$ plots compared with all plots amended with limestone for the susceptible and resistant inbred lines but not the moderate female and male lines (data not shown).

Soil populations of $\boldsymbol{F}$. oxysporum and $\boldsymbol{V}$. dahliae. In the 2009 trial, limestone application rate did not affect the soilborne population of $F$. oxysporum or $V$. dahliae detected at the beginning $(P=0.3910$ and 0.1478 , respectively) or the end $(P=0.3237$ and 0.2859 , respectively) of the season, although the $F$. oxysporum population more than doubled by the end of the season across all limestone rates, from 1,951 to $4,989 \mathrm{CFU} / \mathrm{g}$ of soil. At the end of the 2009 trial, a smaller F. oxysporum population was detected in soil from plots planted with the resistant female compared with plots with the susceptible and moderate inbreds $(3,802$ versus 4,874 and $5,339 \mathrm{CFU} / \mathrm{g}$ of soil, respectively; $P=0.0425)$. There was no effect of inbred line on the soilborne $V$. dahliae population $(P=0.3654)$ but soil in plots fertilized with $\mathrm{NO}_{3}{ }^{-}-\mathrm{N}$ had more $V$. dahliae $(47.9 \mathrm{CFU} / \mathrm{g}$ of soil) at the end of the 2009 season than soil from plots fertilized with $\mathrm{NH}_{4}{ }^{+}-\mathrm{N}$ (25.3 CFU/g of soil) $(P=0.0460)$.

Plating soil samples collected on 7 May, 14 July, and 5 September 2010 did not indicate a significant effect of limestone amendment rate on soilborne $F$. oxysporum population (data not shown). At the start of the 2012 trial, the $F$. oxysporum population had dropped back to levels similar to and, in fact, slightly less than those observed at the start of the 2009 season $(2,089 \mathrm{CFU} / \mathrm{g}$ of soil at the beginning of the 2009 trial versus $1,210 \mathrm{CFU} / \mathrm{g}$ of soil at the start of the 2012 trial). In the 2012 trial, limestone application rate did not influence

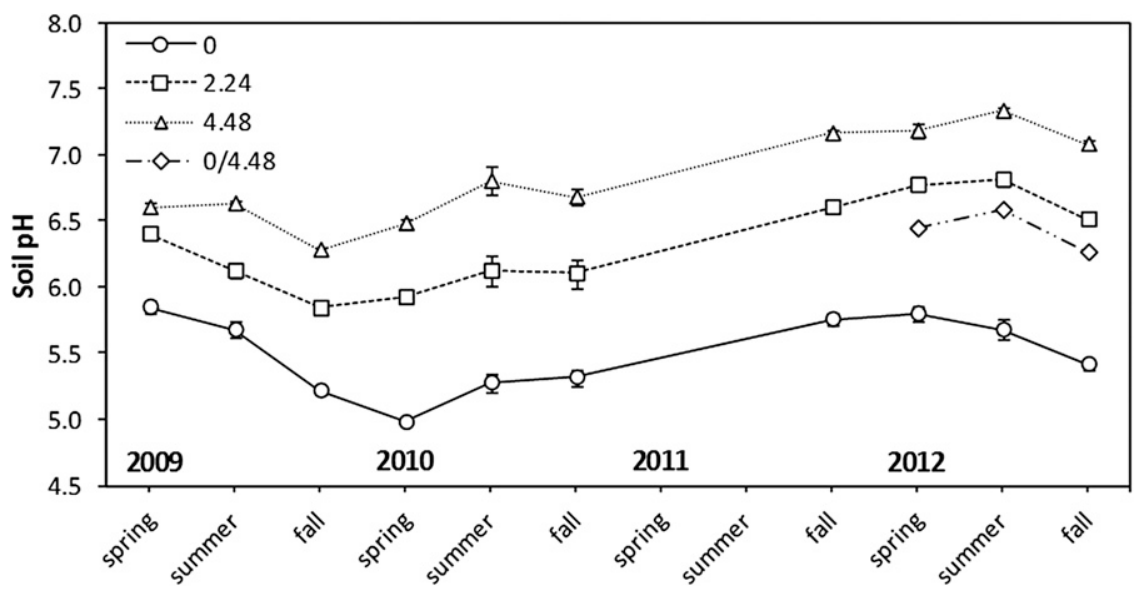

Fig. 7. Effect of limestone application rate on soil pH in a field trial evaluating three annual applications versus a single application of limestone to soil to suppress Fusarium wilt in spinach seed crops in Skagit County, WA. Each data point represents the mean and standard error of five replicate plots, with the exception of fall 2009, when the effect of limestone rate was averaged across three spinach inbred lines and two nitrogen treatments for 30 plots/mean. For soil sampling, 12 cores $(2.5 \mathrm{~cm}$ in diameter by $15 \mathrm{~cm}$ in depth) were collected from each plot and mixed by hand, and a subsample was dried and passed through a 1-mm aperture sieve. Limestone amendment rates were 0, 2.24, and 4.48 tha/year from 2009 to 2011. In the 2012 spinach seed crop trial, a fourth limestone treatment was added in which the control plots that had received no limestone from 2009 to 2011 were divided in half, with one half again receiving $0 \mathrm{t}$ limestone/ha and the other half amended with limestone at 4.48 tha (the $0 / 4.48$ treatment) prior to planting the spinach trial. 
soilborne $F$. oxysporum populations at the early and midseason soil samplings (data not shown) but, by the end of the trial, there were significant effects on soilborne $F$. oxysporum from limestone treatments $(P=0.0374)$ and spinach inbred lines $(P=0.0079)$. By 24 August 2012 , the $0 / 4.48 \mathrm{t} /$ ha plots but not the $0 \mathrm{t} / \mathrm{ha} /$ year plots had a larger population of $F$. oxysporum than the 2.24 and $4.48 \mathrm{t} /$ ha/year plots (6,027 versus 5,147 and 4,822 CFU/g of soil, respectively).

At the start of the 2012 trial, the $V$. dahliae soilborne population was greater across all treatments (average of $64.2 \mathrm{CFU} / \mathrm{g}$ of soil) than at the end of the 2009 season $(36.5 \mathrm{CFU} / \mathrm{g}$ of soil), and the density of the pathogen was lower in the $0 \mathrm{t} / \mathrm{ha} /$ year plots compared with the 2.24 and $4.48 \mathrm{t} / \mathrm{ha} /$ year plots (45.8 versus 72.8 and $81.2 \mathrm{CFU} / \mathrm{g}$ of soil, respectively). By the end of the trial, soilborne $V$. dahliae levels were affected significantly by limestone treatments $(P<0.0001)$ and spinach inbred lines $(P=0.0149)$. The plots amended with limestone at $4.48 \mathrm{t} / \mathrm{ha} /$ year had the most $V$. dahliae (103.1 CFU/g of soil), followed by the $2.24 \mathrm{t} / \mathrm{ha} /$ year plots $(62.1 \mathrm{CFU} / \mathrm{g}$ of soil), the $0 / 4.48 \mathrm{t} / \mathrm{ha}$ plots $(47.8 \mathrm{CFU} / \mathrm{g}$ of soil), and the $0 \mathrm{t} / \mathrm{ha} /$ year plots $(32.6 \mathrm{CFU} / \mathrm{g}$ of soil), with significant differences among all four treatments. Plots planted to the resistant female had significantly more soilborne $V$. dahliae than plots planted to the susceptible and moderate females (75.0 versus 53.7 and $55.5 \mathrm{CFU} / \mathrm{g}$ of soil, respectively).

Soil nutrient analyses. In both the 2009 and 2012 trials, soil nutrient analyses for soil samples collected periodically through the season revealed significant effects of limestone treatments on some soil chemical and physical properties. Details of the effects were reported by Gatch (2013), with a summary of the main effects reported in this article. The limestone treatments affected soil $\mathrm{pH}$ significantly in the 2009 trial, and soil $\mathrm{pH}$ decreased gradually through the 2009 season (Fig. 7). Plots treated with limestone at $4.48 \mathrm{t} / \mathrm{ha}$ had a higher $\mathrm{pH}$ than plots with $2.24 \mathrm{t} / \mathrm{ha}$, and plots with $2.24 \mathrm{t} / \mathrm{ha}$ had a higher $\mathrm{pH}$ than plots with $0 \mathrm{t} / \mathrm{ha}$, with the exception of $28 \mathrm{July}$, when soil $\mathrm{pH}$ did not differ significantly between the 2.24 and 4.48 t/ha plots. There were no significant effects of limestone treatment on soil OM or CEC in the 2009 trial (data not shown).

Soil $\mathrm{NO}_{3}{ }^{-}-\mathrm{N}$ levels decreased with increasing limestone application rate for soil samples collected on 8 and 28 July and 19 August 2009 (data not shown). By 8 July, soil in plots with limestone at $4.48 \mathrm{t} / \mathrm{ha}$ had less $\mathrm{NO}_{3}{ }^{-}-\mathrm{N}(9.3 \mathrm{mg} / \mathrm{kg})$ than plots with $0 \mathrm{t} / \mathrm{ha}$ $(15.7 \mathrm{mg} / \mathrm{kg})$; and, by 19 August, soil $\mathrm{NO}_{3}{ }^{-}-\mathrm{N}$ in both the $0 \mathrm{t} / \mathrm{ha}$ plots $(64.0 \mathrm{mg} / \mathrm{kg})$ and the $2.24 \mathrm{t} / \mathrm{ha}$ plots $(51.0 \mathrm{mg} / \mathrm{kg})$ was greater than in soil from the $4.48 \mathrm{t} / \mathrm{ha}$ plots $(33.3 \mathrm{mg} / \mathrm{kg})$. Changes in soil $\mathrm{NH}_{4}{ }^{+}-\mathrm{N}$ levels associated with limestone treatments were only significant for soil samples collected at the start of the 2009 trial (5 May), when a greater concentration of this cation was detected in the $4.48 \mathrm{t} / \mathrm{ha}$ plots $(1.55 \mathrm{mg} / \mathrm{kg})$ compared with the $0 \mathrm{t} / \mathrm{ha}$ plots $(1.23 \mathrm{mg} / \mathrm{kg})$. Limestone application rate affected soil $\mathrm{Ca}$ significantly throughout the 2009 trial, with more $\mathrm{Ca}$ in the $4.48 \mathrm{t} / \mathrm{ha}$ plots than the $2.24 \mathrm{t} / \mathrm{ha}$ plots, and more $\mathrm{Ca}$ in the $2.24 \mathrm{t} / \mathrm{ha}$ plots than the $0 \mathrm{t} / \mathrm{ha}$ plots; by the end of the trial, soil Ca was 3.52, 4.88, and $5.83 \mathrm{meq} / 100 \mathrm{~g}$ in the 0 , 2.24 , and $4.48 \mathrm{t} / \mathrm{ha}$ plots, respectively (data not shown). Increasing the rate of limestone application decreased soil Mn at all six sampling dates in 2009 and decreased soil $\mathrm{Zn}$ at four of the six sampling dates (27 May, 8 and 28 July, and 19 August). On 8 and 28 July, soil Fe was less concentrated in plots amended with limestone at $4.48 \mathrm{t} / \mathrm{ha}$ (41.5 and $38.0 \mathrm{mg} / \mathrm{kg}$, respectively) than in plots with $2.24 \mathrm{t} / \mathrm{ha}$ $(57.0$ and $58.3 \mathrm{mg} / \mathrm{kg}$, respectively) or $0 \mathrm{t} / \mathrm{ha}(63.0$ and $57.3 \mathrm{mg} / \mathrm{kg}$, respectively). Limestone application rates did not affect concentration of P or B in the soil at any sampling dates in the 2009 trial but, by the end of that trial, soil $\mathrm{K}, \mathrm{Mg}$, and $\mathrm{S}$ were significantly less concentrated in plots with the highest rate of limestone amendment compared with nonamended plots and plots with $2.24 \mathrm{t}$ limestone/ha, with no significant difference between the latter two treatments (data not shown).

In the 2012 trial, limestone treatments significantly affected soil $\mathrm{pH}, \mathrm{NO}_{3}{ }^{-}-\mathrm{N}, \mathrm{Mn}, \mathrm{Zn}$, and $\mathrm{Fe}$ at all three sampling dates (9 May, 9 July, and 24 August); and $\mathrm{CEC}, \mathrm{NH}_{4}{ }^{+} \mathrm{N}, \mathrm{P}, \mathrm{Ca}$, and $\mathrm{S}$ at one or two of the sampling dates. Limestone treatments did not affect soil $\mathrm{OM}, \mathrm{B}$, and $\mathrm{Mg}$ levels. Soil $\mathrm{pH}$ increased slightly from 9 May to 9 July 2012, then decreased by 24 August for all limestone treatments
(Fig. 7). However, in plots that received limestone at 2.24 and $4.48 \mathrm{t} / \mathrm{ha} /$ year for 4 years, soil $\mathrm{pH}$ was higher at the start $(\mathrm{pH}$ of 6.77 and 7.18, respectively, on 9 May) and end (6.51 and 7.08, respectively on 24 August) of the 2012 season compared with the end of 2009 (Fig. 7). Furthermore, plots that received a single application of limestone at $4.48 \mathrm{t}$ /ha just prior to planting the 2012 spinach trial had a lower $\mathrm{pH}$ than plots amended with 2.24 or 4.48 t/ha/year for 4 years, indicating that a greater shift in soil $\mathrm{pH}$ had resulted from annual applications of limestone over 4 years compared with a single application.

On 9 May 2012, soil from plots amended with limestone at 2.24 and $4.48 \mathrm{t} / \mathrm{ha} /$ year had more $\mathrm{NO}_{3}{ }^{-}-\mathrm{N}(5.84$ and $5.60 \mathrm{mg} / \mathrm{kg}$, respectively) compared with soil from $0 / 4.48 \mathrm{t} / \mathrm{ha}$ and $0 \mathrm{t} / \mathrm{ha} /$ year plots (4.84 and $4.04 \mathrm{mg} / \mathrm{kg}$, respectively). This reversed over the course of the season so that, by the middle and end of the season, the nonamended plots ( 0 t/ha/year) had more soil $\mathrm{NO}_{3}{ }^{-} \mathrm{N}$ (15.12 and $17.4 \mathrm{mg} / \mathrm{kg}$, respectively) than plots to which limestone had been applied (6.89 to $12.26 \mathrm{mg} / \mathrm{kg}$ ). On 9 July, soil from the $0 \mathrm{t} / \mathrm{ha} / \mathrm{year}$ plots had less $\mathrm{NH}_{4}{ }^{+}-\mathrm{N}(0.76 \mathrm{mg} / \mathrm{kg})$ than plots to which limestone had been applied (1.66 to $2.09 \mathrm{mg} / \mathrm{kg})$. At the start and middle of the season, soil $\mathrm{Ca}$ increased with increasing limestone application rate but, by the end of the season, these differences were not significant (i.e., by the end of this 4-year trial, there were no significant effects of limestone application rates on soil Ca level). Soil Mn, Zn, and $\mathrm{Fe}$ were lower in all the limestone-amended plots than in the nonamended plots. At the start of the season, $0 \mathrm{t} / \mathrm{ha} /$ year plots had $\mathrm{Mn}$ at $3.29 \mathrm{mg} / \mathrm{kg}$ of soil compared with 1.31 to $1.18 \mathrm{mg} / \mathrm{kg}$ of soil in limestone-amended plots (with no significant differences among the three amendment rates). The effects of limestone treatments on soil Mn were most distinct by the end of the season, with the most Mn detected in $0 \mathrm{t} / \mathrm{ha} /$ year plots $(3.51 \mathrm{mg} / \mathrm{kg})$, followed in order by $0 / 4.48 \mathrm{t} / \mathrm{ha}(1.17 \mathrm{mg} / \mathrm{kg}), 2.24 \mathrm{t} / \mathrm{ha} /$ year $(0.99 \mathrm{mg} / \mathrm{kg})$, and $4.48 \mathrm{t} / \mathrm{ha} /$ year $(0.84 \mathrm{mg} / \mathrm{kg})$ plots. Similar effects on soil $\mathrm{Zn}$ and Fe were observed throughout the season, with available levels of these micronutrients least in $4.48 \mathrm{t} / \mathrm{ha} /$ year plots and greatest in $0 \mathrm{t} / \mathrm{ha} /$ year plots.

\section{Discussion}

Alkaline soils generally are less conducive to Fusarium wilts of many crops (Jones et al. 1989), which is thought to explain why the disease does not limit spinach seed production in Denmark (van Veldhuizen 2011) as well as fresh-market and processing spinach production in southern Texas (J. Schafer, personal communication), where soils naturally are alkaline and calcareous. In contrast, long-term persistence of $F$. oxysporum $\mathrm{f}$. sp. spinaciae is routine in the low-pH soils typical of the maritime PNW, sometimes even when rotations out of spinach seed crops approach 15 to 20 years (Foss and Jones 2005; Gatch and du Toit 2015). This 4-year field trial demonstrates that the suppression of spinach Fusarium wilt achieved with a single limestone application at 2.24 or $4.48 \mathrm{t} / \mathrm{ha}$ in the spring of planting a spinach seed crop in the maritime PNW (du Toit et al. 2007, 2008; Gatch et al. 2011) can be augmented by annual applications of limestone at similar rates for three seasons preceding a spinach seed crop. The hypothesis was based on prior research observations that soils in the Skagit Valley reverted to an acid state by the end of the season in which a single limestone application of $4.48 \mathrm{t} / \mathrm{ha}$ elevated soil $\mathrm{pH}$ close to 7.0 from $<6.0$ (du Toit et al. 2007, 2008). The annual limestone applications of $4.48 \mathrm{t} / \mathrm{ha}$ for 4 years in this study raised soil $\mathrm{pH}$ above 7.0 from $<6.0$ the first year, and stabilized the $\mathrm{pH}$ above 7.0 through the fourth season. This was accompanied by an average $20 \%$ reduction in wilt incidence midseason, $33 \%$ increase in spinach plant biomass, and $45 \%$ increase in spinach seed yield compared with plots amended once with limestone at $4.48 \mathrm{t} / \mathrm{ha}$ the spring of planting, and even greater benefits compared with nonamended plots. Although the study did not compare two or three annual applications with the four annual limestone applications, and was limited to one field site, the annual applications of either 2.24 or $4.48 \mathrm{t} / \mathrm{ha} / \mathrm{year}$ for 4 years similarly enhanced suppression of spinach Fusarium wilt. The results are consistent with studies conducted in the 1970s in Florida on the use of limestone amendments to suppress Fusarium wilts of tomato, watermelon, chrysanthemum, and 
other crops (Jones et al. 1989), although those studies did not evaluate sequential, annual applications of limestone.

Limestone-mediated suppression of Fusarium wilt in this study was influenced significantly by the susceptibility to Fusarium wilt of the spinach parent lines evaluated. In some years, the suppressive effects were more evident for the susceptible line than the partially resistant line, as in the 2009 trial. In the 2012 trial, however, the partially resistant line had the greatest increase in seed yield and greatest decline in incidence and severity of wilt symptoms with increasing rate of limestone application compared with the moderately susceptible and highly susceptible inbred lines. It is likely that nuances of temperature and precipitation each season affected the interactions of $F$. oxysporum f. sp. spinaciae with spinach parent lines and rates of limestone application. In 2009, the wet, cool spring was followed by a hot, dry summer that created ideal conditions for Fusarium wilt development. The disease advanced rapidly, making wilt incidence assessment after the middle of July ineffectual for differentiating treatment effects. Wilt was slower to progress and yields were greater in the 2012 season, which was cooler and milder than in 2009. This may have enhanced the observed benefit of annual limestone applications on spinach seed production and Fusarium wilt suppression in the 2012 trial. Nevertheless, wilt incidence reached 100\% toward the end of the season in both 2009 and 2012, and plots not treated annually with limestone or amended with a single limestone application the spring of planting had more severe wilt compared with plots with annual applications at either 2.24 or $4.48 \mathrm{t} / \mathrm{ha}$ for 4 years, based on the final disease rating in 2012.

The 2012 field trial was arranged in the same plots with the same treatments (except for the $\mathrm{NO}_{3}{ }^{-}-\mathrm{N}$ versus $\mathrm{NH}_{4}{ }^{+}-\mathrm{N}$ fertilizers) as the 2009 trial. As shown by the 2009 results, spinach inbred line susceptibility to Fusarium wilt influenced the amount of soilborne $F$. oxysporum detected at the end of the season, which was measured as an indirect indicator of the effects of spinach line on the soilborne population of F. oxysporum f. sp. spinaciae. Quantification of the pathogen population would have required greenhouse pathogenicity testing of an adequate subsample of $F$. oxysporum to distinguish strains of $F$. oxysporum f. sp. spinaciae, other formae speciales, and nonpathogenic $F$. oxysporum, which was not feasible for a trial of this size. As noted previously, the real-time PCR assay for the spinach Fusarium wilt pathogen developed by Okubara et al. (2013) proved to have an unacceptably high rate of cross-reaction with nonpathogenic strains of $F$. oxysporum isolated from spinach plants, seed, or soil in which spinach seed crops had been grown in western Washington; therefore, that assay was not utilized in this study. Although there were no significant effects of limestone application rate or form of $\mathrm{N}$ fertilizer on the $F$. oxysporum population detected at the end of the 2009 season, there was a significant decrease in $F$. oxysporum population by the end of the 2009 trial in plots planted with the resistant spinach female line compared with plots planted with the susceptible and moderate female lines. This may have reduced disease pressure in the same plots planted to the same resistant female line in 2012 compared with plots planted with the moderate and susceptible inbreds. However, the lack of significant limestone treatment effects on $F$. oxysporum population in the 2009 trial suggests that differences among these treatments in 2012 were not associated significantly with effects of the 2009 treatments on the pathogen population.

Soil chemical properties and plant nutrient status were assessed in both the 2009 and 2012 trials to characterize chemical shifts in soil and plant tissue as a result of the limestone treatments. Plant genotype can influence the uptake and accumulation of mineral elements (Clárk 1983); therefore, the effects of spinach parent line also were evaluated in the nutrient analyses. Raising soil $\mathrm{pH}$ can reduce the availability of certain soil nutrients, particularly Fe, Mn, and Zn, through the formation of insoluble metal hydroxides (Havlin et al. 1999). In Denmark, where spinach seed crops are produced on soils with a $\mathrm{pH}$ of 7.5 to 8.0 , foliar sprays of $\mathrm{Mn}$ and $\mathrm{Zn}$ are necessary to avoid deficiencies of these micronutrients $(\mathrm{H}$. van Veldhuizen, personal communication). In the 2009 trial, soil Mn levels were reduced significantly with increasing rates of limestone amendment and, at some sampling dates, fell to $<1.5 \mathrm{mg} / \mathrm{kg}$, the boundary between deficiency and sufficiency for most crops (Marx et al. 1996). In 2012 , only soils from plots that received no limestone all 4 years had $\mathrm{Mn}$ concentrations within the sufficiency range. Soil $\mathrm{Zn}$ was also reduced with limestone amendments in both 2009 and 2012 and, by 2012, was slightly below the recommended sufficiency of $1.0 \mathrm{mg} / \mathrm{kg}$ midseason and at the end of the season.

These soil micronutrient deficiencies associated with the limestone applications were expected. One theory about the mechanisms of Fusarium wilt suppression with limestone application is that raising soil $\mathrm{pH}$ limits availability of these so-called "acid micronutrients" for the pathogen, thereby limiting growth and virulence of the pathogen (Jones et al. 1989; Woltz and Jones 1968). Regardless of whether depriving the pathogen of these micronutrients contributes to limestone-based suppression of Fusarium wilt, depriving the plant of these essential elements is undesirable. Therefore, as a precaution against the development of spinach plant deficiencies, a foliar Mn and $\mathrm{Zn}$ application was made to the entire trial in 2012 at the rosette stage of growth. Plants in plots amended with limestone at $4.48 \mathrm{t} / \mathrm{ha}$ had significantly lower $\mathrm{Zn}$ and $\mathrm{Mn}$ in both 2009 and 2012 compared with plants in plots not amended with limestone. In the 2012 trial, annual applications of limestone at $4.48 \mathrm{t} / \mathrm{ha} /$ year resulted in lower plant $\mathrm{Zn}$ and Mn levels compared with plants in plots amended only once with the same amount of limestone, just prior to planting the 2012 spinach trial. Plant $\mathrm{Zn}$ and $\mathrm{Mn}$ levels did not fall below the sufficiency range in any of the 2012 plots (Olsen's Agricultural Laboratory 2013). Soil Fe but not plant Fe was reduced in plots with limestone at $4.48 \mathrm{t} / \mathrm{ha} /$ year. Further evaluation of annual limestone applications in different fields will help determine whether prophylactic micronutrient foliar sprays are critical to the successful use of annual limestone amendments as a management practice by spinach seed growers in this region.

Another theory regarding the mechanisms of Fusarium wilt suppression achieved with soil limestone application is that Ca provided by the limestone is beneficial for plant defense responses, because $\mathrm{Ca}$ fortifies cell wall structure by cross-linking pectins and is involved in cellular defense signaling (Marschner 1995). Although some studies have shown that $\mathrm{pH}$ elevation, not $\mathrm{Ca}$, is implicated in limestonemediated Fusarium wilt suppression (Jones and Woltz 1969), others provide evidence for the involvement of $\mathrm{Ca}$ in reducing Fusarium wilt development (Corden 1965). Soil and plant Ca levels were assessed in this study to determine whether results were confounded by a $\mathrm{Ca}$ deficiency in non-limestone-amended soils. A soil Ca level of 5 meq per $100 \mathrm{~g}$ of soil and a spinach plant level of $0.6 \%$ are considered adequate for normal plant growth (Marx et al. 1996; Olsen's Agricultural Laboratory 2013). In 2009, soil Ca was $<5$ meg per $100 \mathrm{~g}$ of soil in plots amended with limestone at 0 and $2.24 \mathrm{t} / \mathrm{ha}$ whereas, in 2012, only plots not amended with limestone were below this level, and only at the first two sampling dates. Furthermore, spinach $\mathrm{Ca}$ levels were above the sufficiency range in both trials. There were no significant differences in plant $\mathrm{Ca}$ (or in soil $\mathrm{Ca}$ by the end of the trial) associated with limestone treatments in 2012, which suggests that Ca probably did not play a critical role in limestonemediated spinach Fusarium wilt suppression.

Potential disease management strategies designed for spinach seed crops in the Skagit Valley of Washington State must be vetted for possible negative consequences as well as potential benefits to crops grown in rotation with spinach seed, the most valuable of which is fresh-market potato (McMoran 2011). Some studies have indicated that elevation of soil $\mathrm{pH}$ through limestone applications is associated with an increase in the incidence of potato common scab caused by Streptomyces scabies, which results in cosmetic tuber damage and can lead to significant economic losses (Lambert and Manzer 1991; Odland and Allbritten 1950). However, other factors, most notably soil moisture at the time of lenticel development in the tubers, are far more significant in the risk of common scab (Lapwood and Adams 1975). In this trial, potato yield and tuber diseases such as common scab were not affected significantly by the different limestone treatments.

Also important for grower adoption of annual applications of limestone in spinach seed production are analyses demonstrating the economic viability of this longer-term approach to Fusarium wilt 
management. Minimum increases in a typical spinach seed crop that yields about $1,350 \mathrm{~kg} / \mathrm{ha}$, required to justify the cost of applying limestone at 2.24 or $4.48 \mathrm{t} / \mathrm{ha}$, were calculated to be 52 and $91 \mathrm{~kg}$ seed/ha, respectively, based on estimated expenses for the purchase, application, and incorporation of agricultural limestone at the two rates evaluated (J. Schafer, Schafer Ag Services; and P. Klein, Rijk Zwaan, personal communications). This represents yield increases of 4 and $7 \%$, respectively. In the 2009 trial, soil amendment with limestone at $2.24 \mathrm{t} / \mathrm{ha}$ approximately doubled spinach seed yield, and annual application of $4.48 \mathrm{t} / \mathrm{ha}$ increased yields by $169 \%$ compared with yields from plots with no limestone amendment; therefore, the minimum required increases in seed yield were far exceeded. To cover expenses for annual limestone applications of $4.48 \mathrm{t} / \mathrm{ha}$ for 3 or 4 years prior to a spinach seed crop, including the year of planting the seed crop, a yield increase of $44 \%$ would be necessary. In the 2012 trial, annual applications of limestone at $4.48 \mathrm{t} / \mathrm{ha}$ for 4 years compared with 0 and $4.48 \mathrm{t} / \mathrm{ha}$ applied once just prior to the seed crop increased spinach seed yields by 150 and $45 \%$, respectively. Further research could be done to determine whether similar seed yield increases can be achieved with just two annual limestone applications prior to planting a spinach seed crop. Any economic analysis should also take into account potential economic benefits of annual limestone applications to crops grown in rotation with spinach, such as brassica crops or table beet (Beta vulgaris) seed crops and various small fruit crops commonly grown in the region. For example, limestone is applied routinely to brassica crops to suppress clubroot caused by Plasmodiophora brassicae, and to raspberry (Rubus idaeus) crops to suppress Phytophthora root rot caused by Phytophthora rubi (Pacific Northwest Plant Disease Management Handbook 2013).

Use of the limestone-mediated Fusarium wilt management strategy will need to address the increased incidence of $V$. dahliaeinfected seed detected at the greater limestone amendment rates. Verticillium wilts of many crops are favored by alkaline soils or $\mathrm{NO}_{3}{ }^{-}-\mathrm{N}$ fertilization, which is the opposite response of most Fusarium wilts (Dutta 1981; Elmer and Ferrandino 1994; Jones and Woltz 1972). The $11.5 \%$ incidence of $V$. dahliae on seed harvested from plots amended with limestone at $4.48 \mathrm{t} / \mathrm{ha} /$ year in the 2012 trial would cause a commercial spinach seed lot to be rejected for export to Mexico, which has a phytosanitary requirement of $<10 \% \mathrm{~V}$. dahliae on spinach seed (International Phytosanitary Certificate 2003). Many commercial spinach seed lots, regardless of the region of production, sustain some level of $V$. dahliae infection (du Toit et al. 2005). However, spinach seed has come under recent scrutiny as one of several possible sources of $V$. dahliae strains found in California fields where lettuce is grown in rotation with spinach and other crops susceptible to Verticillium wilt. Because Verticillium wilt has emerged as a major disease of lettuce (Atallah et al. 2010), these findings underline the importance of taking steps to reduce $V$. dahliae incidence on spinach seed. Spinach seed treatments have been identified that reduced $V$. dahliae incidence on seed from 64 to $<10 \%$ (du Toit and Correll 2012; du Toit et al. 2010), which indicates that contending with seedborne $V$. dahliae in harvested spinach seed will prove easier than managing Fusarium wilt in spinach seed crops, because there are currently few effective and economically viable treatments for Fusarium wilt (du Toit et al. 2014).

A crop that requires an 8- to 15 -year rotation to avoid significant losses to a disease, and that cannot be relocated to new regions of the United States because of unique, stringent climatic and geographic requirements for seed production, is worthy of extraordinary measures to protect. Until Fusarium wilt management practices are developed that are effective and economically viable, the acreage suitable for spinach seed production in the United States will remain severely restricted as a result of the risk posed by this disease. This study demonstrates the potential for enhanced suppression of Fusarium wilt with annual applications of limestone to the soil for several years. Annual applications of limestone enabled economically viable spinach seed production on a 4-year rotation in this study. This demonstrates the potential to reduce the required rotation interval by as much as $50 \%$ for spinach seed crops, thereby doubling the capacity for spinach seed production in the United States.

\section{Acknowledgments}

In-kind and financial support for this project was received from participating spinach seed companies as well as the Puget Sound Seed Growers' Association, Washington State Commission for Pesticide Registration, United States Department of Agriculture (USDA) Sustainable Agriculture Research and Education Graduate Student Fellow Grant GW08-005, USDA Western Region Integrated Pest Management Grant 2009-34103-19910, the Alfred Chrisitanson Endowed Fellowship, and the Robert MacDonald Vegetable Seed Memorial Fund. We thank M. Derie, B. Holmes, L. Brissey, A. V. Alcala, R. Dralle, D. Gorton, M. Reichlin, and J. Roozen, as well as interns and summer employees in the Vegetable Seed Pathology program at Washington State University, for their excellent technical assistance; and T. Paulitz and M. Mazzola for providing valuable reviews of the manuscript.

\section{Literature Cited}

Albert, W. B. 1946. The effects of certain nutrient treatments upon the resistance of cotton to Fusarium vasinfectum. Phytopathology 36:703-716.

Association of Official Seed Analysts. 2008. Pages 6-57 in: Germination Tests. Rules for Testing Seeds, Ithaca, NY.

Atallah, Z. K., Maruthachalam, K., du Toit, L. J., Koike, S. T., Davis, R. M., Klosterman, S. J., Hayes, R. J., and Subbarao, K. V. 2010. Population analyses of the vascular plant pathogen Verticillium dahliae detect recombination and transcontinental gene flow. Fungal Genet. Biol. 47:416-422.

Atallah, Z. K., Maruthachalam, K., Vallad, G. E., Davis, R. M., Klosterman, S. J., and Subbarao, K. V. 2011. Analysis of Verticillium dahliae suggests a lack of correlation between genotypic diversity and virulence phenotypes. Plant Dis. 95:1224-1232.

Baker, K. F., and Cook, R. J. 1974. Biological Control of Plant Pathogens. W. H. Freeman, San Francisco.

Bhat, R. G., and Subbarao, K. V. 1999. Host range specificity in Verticillium dahliae. Phytopathology 89:1218-1225.

Clárk, R. B. 1983. Plant genotype differences in the uptake, translocation, accumulation, and use of mineral elements required for plant growth. Plant Soil 72:175-196.

Corden, C. E. 1965. Influence of calcium nutrition on Fusarium wilt of tomato and polygalacturonase activity. Phytopathology 55:222-224.

Correll, J. C., Morelock, T. E., Black, M. C., Koike, S. T., Brandenberger, L. P., and Dainello, F. J. 1994. Economically important diseases of spinach. Plant Dis. 78:653-660.

du Toit, L. J. 2004. Management of diseases in seed crops. Pages 675-677 in: Encyclopedia of Plant and Crop Science. R. M. Goodman, ed. M. Dekker, New York

du Toit, L. J. 2011. Selecting a spinach seed assay for Verticillium: Preliminary results of an ISHI ring test. Page 28 in: Proc. 2011 Int. Spinach Conf. Amsterdam.

du Toit, L. J., and Correll, J. 2012. Management of Verticillium in spinach. In: 51st Am. Seed Trade Assoc. Veg. Flower Seed Conf. Tampa, FL.

du Toit, L. J., Derie, M. L., and Brissey, L. M. 2008. Effect of agricultural limestone amendments on Fusarium wilt and Verticillium wilt in a spinach seed crop, 2007. Plant Dis. Manage. Rep. 2:V042.

du Toit, L. J., Derie, M. L., Brissey, L. M., and Cummings, J. A. 2007. Evaluation of limestone amendments for control of Fusarium wilt in a spinach seed crop, 2006. Plant Dis. Manage. Rep. 1:V091.

du Toit, L. J., Derie, M. L., Brissey, L. M., and Holmes, B. J. 2010. Evaluation of seed treatments for management of seedborne Verticillium and Stemphylium in spinach, 2009. Plant Dis. Manage. Rep. 4:ST038.

du Toit, L. J., Derie, M. L., Gatch, E. W., Brissey, L. M., and Holmes, B. 2011. Effect of agricultural limestone amendments on Fusarium and Verticillium wilts in a spinach seed crop, 2008. Plant Dis. Manage. Rep. 5:V117.

du Toit, L. J., Derie, M. L., and Hernandez-Perez, P. 2004. Evaluation of fungicides for management of leaf spot in spinach seed crops. Fungic. Nematicide Tests 60:V044.

du Toit, L. J., Derie, M. L., and Hernandez-Perez, P. 2005. Verticillium wilt in spinach seed production. Plant Dis. 89:4-11.

du Toit, L. J., Derie, M. L., Holmes, B. J., and Youngquist, C. P. 2014. Effect of Proline and a biosolids compost on Fusarium and Verticillium wilts in a spinach seed crop, 2013. Plant Dis. Manage. Rep. 8:V280.

du Toit, L. J., and Gatch, E. W. 2009. Increasing the capacity for spinach seed production in the United States by promoting soil suppression of Fusarium wilt. Page 7 in: The Western Front, October 2009. Western Integrated Pest Management Center.

Dutta, B. K. 1981. Effect of the chemical and physical condition of the soil on Verticillium wilt of Antirrhinum. Plant Soil 63:217-225.

Edgerton, C. W. 1918. A study of wilt resistance in the seed bed. Phytopathology 8:5-14.

Elmer, W. H., and Ferrandino, F. J. 1994. Comparison of ammonium sulfate and calcium nitrate fertilization effects on Verticillium wilt of eggplant. Plant Dis. 78:811-816.

Everett, P. H., and Blazquez, C. H. 1967. Influence of lime on the development of Fusarium wilt of watermelons. Proc. Fla. State Hortic. Soc. 80:143-148.

Fang, X., You, M. P., and Barbetti, M. J. 2012. Reduced severity and impact of Fusarium wilt on strawberry by manipulation of soil $\mathrm{pH}$, soil organic amendments and crop rotation. Eur. J. Plant Pathol. 134:619-629.

Feng, C., Mansouri, S., Bluhm, B. H., du Toit, L. J., and Correll, J. C. 2014. Multiplex real-time PCR assays for detection of spinach seedborne pathogens. J. Appl. Microbiol. 117:472-484. 
Foss, C. R., and Jones, L. J. 2005. Crop Profile for Spinach Seed in Washington. U.S. Dep. Agric. Natl. Pest Manage. Centers. http://ipmcenters.org/index.cfm/ center-products/crop-profiles/

Gatch, E. W. 2013. Management of Fusarium wilt in spinach seed crops in the maritime Pacific Northwest USA. Ph.D. dissertation, Washington State University, Pullman.

Gatch, E. W., and du Toit, L. J. 2015. A soil bioassay for predicting the risk of spinach Fusarium wilt. Plant Dis. 99:512-526.

Gatch, E. W., du Toit, L. J., Derie, M. L., Holmes, B. J., and Brissey, L. M. 2011. Effect of agricultural limestone and nitrogen fertilizers on Fusarium wilt and Verticillium wilt in a spinach seed crop, 2009. Plant Dis. Manage. Rep. 5:V118.

Goud, J. C., and Termorshuizen, J. 2003. Quality of methods to quantify microsclerotia of Verticillium dahliae in soil. Eur. J. Plant Pathol. 109:523-534.

Havlin, J. L., Beaton, J. D., Tisdale, S. L., and Nelson, W. L. 1999. Soil Fertility and Fertilizers, 6th ed. Prentice Hall, Upper Saddle River, NJ.

Höper, H., Steinber, C., and Alabouvette, C. 1995. Involvement of clay type and $\mathrm{pH}$ in the mechanisms of soil suppressiveness to Fusarium wilt of flax. Soil Biol. Biochem. 27:955-967.

Hopkins, D. L., and Elmstrom, G. W. 1976. Effect of soil pH and nitrogen source on Fusarium wilt of watermelon on land previously cropped in watermelons. Proc. Fla. State Hortic. Soc. 89:141-143.

Hungerford, C. W. 1923. A Fusarium wilt of spinach. Phytopathology 13:205-209.

Iglesias-Garcia, A. M., Villarroel-Zeballos, M. I., Feng, C., du Toit, L. J., and Correll, J. C. 2013. Pathogenicity, virulence, and vegetative compatibility grouping of Verticillium isolates from spinach seed. Plant Dis. 97:1457-1469.

International Phytosanitary Certificate. 2003. International Phytosanitary Certificate No. 4051. Phytosanitary Federal Law of the Mexican United States, Phytosanitary Regulation and Inspection Department, Mexico.

Islas, C. M. 2012. Fusarium wilt caused by Fusarium oxysporum f. sp. fragariae: An emerging disease of strawberry in California. MS thesis, University of California, Davis.

Jones, J. P., Engelhard, A. W., and Woltz, S. S. 1989. Management of Fusarium wilt of vegetables and ornamentals by macro- and microelements. Pages 18-32 in: Soilborne Plant Pathogens: Management of Disease with Macro and Microelements. A. W. Engelhard, ed. American Phytopathological Society, St. Paul, MN.

Jones, J. P., and Overman, A. J. 1971. Control of Fusarium wilt of tomato with lime and soil fumigants. Phytopathology 61:1415-1417.

Jones, J. P., and Woltz, S. S. 1969. Fusarium wilt (race 2) of tomato: Calcium, pH, and micronutrient effects on disease development. Plant Dis. Rep. 53:276-279.

Jones, J. P., and Woltz, S. S. 1970. Fusarium wilt of tomato: Interaction of soil liming and micronutrient amendments on disease development. Phytopathology $60: 812-813$

Jones, J. P., and Woltz, S. S. 1972. Effect of soil pH and micronutrient amendments on Verticillium and Fusarium wilt of tomato. Plant Dis. Rep. 56:151-153.

Jones, J. P., and Woltz, S. S. 1975. Effect of liming and nitrogen source on Fusarium wilt of cucumber and watermelon. Proc. Fla. State Hortic. Soc. 85: 200-203.

Koike, S. T., Cahn, M., Cantwell, M., Fennimore, S., Lestrange, M., Natwick, E., Smith, R. F., and Takele, E. 2011. Spinach Production in California. Online publication. University of California ANR Publication 7212. http://anrcatalog. ucanr.edu/pdf/7212.pdf

Komada, H. 1975. Development of a selective medium for quantitative isolation of Fusarium oxysporum from natural soils. J. Phytopathol. 8:114-124.

Lambert, D. H., and Manzer, F. E. 1991. Relationship of calcium to potato scab. Phytopathology 81:632-636.

Lambert, D. H., Powelson, M. L., and Stevenson, W. R. 2005. Nutritional interactions influencing diseases of potato. Am. J. Potato Res. 82:309-319.

Lapwood, D. H., and Adams, M. I. 1975. Mechanisms of control of common scab by irrigation. Pages 123-129 in: Biology and Control of Soil-Borne Plant Pathogens. G. W. Bruehl, ed. American Phytopathological Society Press, St. Paul, MN.

Marschner, H. 1995. Mineral Nutrition of Higher Plants. Academic Press, San Diego, CA.

Marx, E. S., Hart, J., and Stevens, R. G. 1996. Soil Test Interpretation Guide. Online publication. Oregon State University Extension Service EC 1478. http://ir.library.oregonstate.edu/xmlui/bitstream/handle/1957/14361/ec1478.pdf; sequence $=1$

Matheron, M. E., and Koike, S. T. 2003. First report of Fusarium wilt of lettuce caused by Fusarium oxysporum f. sp. lactucae in Arizona. Plant Dis. 87:1265.

McMoran, D. 2011. 2011 Skagit County Agriculture Statistics. Washington State University Skagit County Extension. http://extension.wsu.edu/skagit/ agriculture/

Metzger, J. D., and Zeevaart, J. A. D. 1985. Spinacia oleracea. Pages 384-392 in: CRC Handbook of Flowering Plants. Vol. IV. A. H. Halevy, ed. CRC Press, Boca Raton, FL.

Odland, T. E., and Allbritten, H. G. 1950. Soil reaction and calcium supply as factors influencing the yield of potatoes and the occurrence of scab. Agron. J. 42:269-275.

Okubara, P., Harrison, L. A., Gatch, E. W., Schroeder, K., Vandemark, G., and du Toit, L. J. 2013. Development and evaluation of a TaqMan real-time PCR assay for Fusarium oxysporum f. sp. spinaciae. Plant Dis. 97:927-937.

Olsen's Agricultural Laboratory. 2013. Plant Tissue Interpretative Guidelines. Online publication. American Agricultural Laboratory, McCook, NE. http:// www.olsenlab.com/guidelines/Plant_Tissue_Interpretative_Guidelines.pdf

Pacific Northwest Plant Disease Management Handbook. 2013. A Pacific Northwest Extension Publication. Online publication. http://pnwhandbooks org/plantdisease/

Peng, H. X., Sivasithamparam, K., and Turner, D. W. 1999. Chlamydospore germination and Fusarium wilt of banana plantlets in suppressive and conducive soils are affected by physical and chemical factors. Soil Biol. Biochem. 31:1363-1374

Scher, F. M., and Baker, R. 1980. Mechanism of biological control in a Fusariumsuppressive soil. Phytopathology 70:412-417.

Schneider, R. W. 1985. Suppression of Fusarium yellows of celery with potassium, chloride, and nitrate. Phytopathology 75:40-48.

Scott, J. C., Gordon, T. R., Shaw, D. V., and Koike, S. T. 2010. Effect of temperature on severity of Fusarium wilt of lettuce caused by Fusarium oxysporum f. sp. lactucae. Plant Dis. 94:13-17.

Sherwood, E. C. 1923. Hydrogen-ion concentration as related to Fusarium wilt of tomato seedlings. Am. J. Bot. 10:537-553.

Smiley, R. W. 1975. Forms of nitrogen and the $\mathrm{pH}$ in the root zone and their importance to root infections. Pages 55-62 in: Biology and Control of Soil-Borne Plant Pathogens. G. W. Bruehl, ed. American Phytopathological Society, St. Paul, MN.

Sorensen, L. H., Schneider, A. T., and Davis, J. R. 1991. Influence of sodium polygalacturonate sources and improved recovery of Verticillium spp. from soil. (Abstr.) Phytopathology 81:1347.

Stover, R. H. 1956. Studies on Fusarium wilt of bananas. I. The behavior of F. oxysporum f. sp. cubense in different soils. Can. J. Bot. 34:927-942.

Toussoun, T. A. 1975. Fusarium-suppressive soils. Pages 145-151 in: Biology and Control of Soil-Borne Plant Pathogens. G. W. Bruehl, ed. American Phytopathological Society, St. Paul, MN.

USDA Soil Survey Staff. 2016. Web Soil Survey. Online publication. Soil Survey Staff, Natural Resources Conservation Service, United States Department of Agriculture. http://websoilsurvey.sc.egov.usda.gov/App/HomePage.htm

van Veldhuizen, H. 2011. Can Denmark keep the position as the biggest spinach seed producer in the world? Page 27 in: Proc. 2011 Int. Spinach Conf. Amsterdam.

Western Washington Small Seed Advisory Committee. 1998. Seed field minimum isolation distances for Skagit County, Washington. WWSSAC, Mount Vernon, WA.

Woltz, S. S., and Engelhard, A. W. 1973. Fusarium wilt of chrysanthemum: Effect of nitrogen source and lime on disease development. Phytopathology 63:155-157.

Woltz, S. S., and Jones, J. P. 1968. Micronutrient effects on the in vitro growth and pathogenicity of Fusarium oxysporum f. sp. lycopersici. Phytopathology 58: 336-338.

Woltz, S. S., and Jones, J. P. 1973. Interactions in source of nitrogen fertilizer and liming procedure in the control of Fusarium wilt of tomato. HortScience 8:137-138.

Woltz, S. S., and Jones, J. P. 1981. Nutritional requirements of Fusarium oxysporum: Basis for a disease control system. Pages 340-349 in: Fusarium: Diseases, Biology, and Taxonomy. P. E. Nelson, T. A. Toussoun, and R. Cook, eds. Pennsylvania State University Press, University Park. 